\title{
The P42 peptide and Peptide-based therapies for Huntington's disease
}

\author{
Cecilia Marelli ${ }^{1,2}$ and Florence Maschat ${ }^{1 *}$
}

\begin{abstract}
Huntington's disease (HD) is a progressive neurodegenerative hereditary disease clinically characterised by the presence of involuntary movements, behavioural problems and cognitive decline. The disease-onset is usually between 30 and 50 years of age. HD is a rare disorder affecting approximately 1.3 in 10,000 people in the European Union. It is caused by an expanded CAG repeat in the first exon of the Huntingtin (HTT) gene, leading to an abnormal form of the Huntingtin protein $(\mathrm{Htt}$ ) (polyQHtt), containing $\mathrm{N}$-terminus, enlarged polyglutamine strands of variable length that stick together to form aggregates and nuclear inclusions in the damaged brain cells. Treatments currently used for Huntington's disease are symptomatic and aimed at temporally relieving the symptoms of the disease; although some promising therapies are on study, there is no drug capable of stopping disease progression either in the form of delaying onset or slowing disability progression. The utilization of peptides interacting with polyQ stretches or with Htt protein to prevent misfolding and aggregation of the expanded polyQ protein is a fascinating idea, because of low potential toxicity and ability to target very initial steps in the pathophysiological cascade of the disease, such as aggregation or cleavage process. Indeed, several therapeutic peptides have been developed and were found to significantly slow down the progression of symptoms in experimental models of Huntington's disease. This review is essentially focusing on the latest development concerning peptide strategy. In particular, we focused on a 23aa peptide P42, which is a part of the Htt protein. It is expected to work principally by preventing the abnormal Htt protein from sticking together, thereby preventing pathological consequences of aggregation and improving the symptoms of the disease. In the meantime, as P42 is part of the Htt protein, some therapeutic properties might be linked to the physiological actions of the peptide itself, considered as a functional domain of the Htt protein.
\end{abstract}

Keywords: Huntington's disease, Peptide-based therapy, P42

\section{Background}

Huntington's disease (HD) is an autosomal-dominant, progressive neurodegenerative disorder clinically characterized by the presence of motor dysfunction (chorea, dystonia, extrapyramidal rigidity and akinesia), cognitive decline (early alteration of executive functions, mental flexibility, and attention; later impairment of language, visuospatial and memory functions), and neuropsychiatric symptoms (depression, apathy, anxiety, obsessive/ compulsive behaviours, irritable/aggressive symptoms and sometimes personality changes, and psychosis).

\footnotetext{
*Correspondence: florence.maschat@umontpellier.fr

'Université de Montpellier, Montpellier F-34095, France; Inserm U1 198

MMDN, Montpellier F-34095, France; EPHE, Paris F-75014, France, Montpellier, France

Full list of author information is available at the end of the article
}

Typically, onset of symptoms is in adulthood between 30 and 50 years, but the disorder can manifest at any time between infancy and senescence $[1,2]$. HD is a rare disease and the highest prevalence is estimated to be $1.3 / 10.000$ [3].

HD is caused by an expanded CAG repeat in the first exon of the Huntingtin (HTT) gene [4]; the resulting mutant protein in HD (polyQHtt) contains enlarged polyglutamine repetitions of variable lengths, that stick together and form intranuclear and intracytoplasmic cellular deposits. In initial disease stages, cell loss and reactive gliosis affect predominantly striatal medium spiny neurons, while polyQHtt positive inclusions are found in cortical region; in later disease stages cortical cell loss is found [5-7]. Currently there is no curative treatment for HD; only symptomatic pharmacological 
and non-pharmacological treatments are available with some benefits mainly for motor and psychiatric HD symptoms [8-11]. Unfortunately, there is no drug capable of stopping disease progression either in the form of delaying onset or slowing symptoms progression [12].

The precise physiopathology of HD is complex and involves many mechanisms that have been described $[13,14]$ : protein aggregation, alteration of protein degradation through autophagy [15] or ubiquitin-proteasomesystem (UPS) [16], enhanced proteolytic cleavages [17], transcriptional deregulation and brain-derived nerve factor (BDNF) alteration [18], mitochondrial abnormalities and defective energy metabolism [19-21], cytoskeletal defects and axonal transport alterations [22, 23], loss of wtHtt normal function [24, 25], non cell-autonomous degeneration [26], and neuro-inflammation [27-29].

Based on these different pathogenic mechanisms, several therapeutic approaches have been proposed to date [30]. Among them, here we focus on peptide-based approaches that target different parts of the polyQHtt, preventing aggregate formation of the polyQHtt proteins, and that were further tested for their ability to rescue abnormal cellular processes induced by the expanded polyQ proteins.

\section{Peptide-based therapeutic approach in HD and polyglutamine diseases}

The utilization of peptides interacting with polyQ stretches or with Htt protein to prevent misfolding and aggregation of the expanded polyQ protein is a promising intervention. A summary of the different peptides developed up to now against HD is presented in Tables 1, 2 and 3.

One of the first proposed peptide was a synthetic bivalent Htt-binding peptide containing two stretches of short polyQ regions (25Q), separated by an alpha-helix structure; it co-localized with aggregate of polyQHtt protein and interacted with the polyQHtt. This peptide was able to reduce and delay aggregate formation in a cellular HD model (COS-1 hHtt $\left.{ }^{17 a a}-103 \mathrm{Q}\right)$; moreover it increased survival, reduced eye aggregate formation and degeneration, and inhibited brain aggregate formation in Drosophila HD models [31].

Polyglutamine binding peptide 1 (QBP1) is a 11 aa synthetic peptide identified by a combinatorial screening approach for its specific binding affinity to abnormal expanded polyQ stretch [32]. QBP1 was able to co-localize with and to reduce aggregate formation in cultured cells; in Drosophila HD model it increased survival and decreased eye degeneration and aggregate formation [33]. To allow its efficient cellular delivery, QBP1 was conjugated to short peptides belonging to the group of the peptide transduction domains (PTD) or cell penetrating peptides (CPP), like the Penetratin part of Antennapedia
(Antp) [34] or of the HIV TAT-derived protein, allowing the access to the cytoplasm and the nucleus after their internalization by living cells [35-38]. This technique overcame the problems of intestinal membrane passage and increased bioavailability after administration of the modified peptide in Drosophila food: oral administration of Antp-QBP1 to polyQ-Macado Joseph Disease (MJD) flies, a Drosophila model of the polyQ-induced spinocerebellar ataxia 3 disease (SCA3), remarkably delayed premature adult flies death; in addition, polyQ-MJD flies administered with Antp-QBP1 had significantly fewer polyQ aggregates in the eye imaginal disc of third instar larvae, compared to the control flies [39]. The therapeutic effect of Antp-QBP1 administration was also tested on a R6/2 mouse model of the polyQ disease [40]: intraperitoneal injection of Antp-QBP1 resulted in a slight improvement of the weight loss, but did not improve the other phenotypes such as motor dysfunction and premature death; no significant decrease of polyQ inclusion body formation could be detected. After intra-cerebroventricular and intra-striatal injection of Antp-QBP1 or TAT-QBP1 peptides into wild type (wt) C57BL/6 mouse, PTD-QBP1 showed limited diffusion into the brain, restricted to a few cell layers around the ventricles with however a more efficient diffusion for Antp-QBP1. After either intraperitoneal or intracarotid arterial injection, no detectable levels of PTD-QBP1 were found into the brain. The authors suggested that lack of efficacy was due either to low targeting of PTD-QBP1 into the brain or to a too severe phenotype in the R6/2 mouse model [40].

More recently, a caspase- 6 inhibiting peptide, targeting the cleavage of the polyQHtt protein, a key step in HD pathogenesis, was proposed and tested on the full-length 97Q-mHtt transgenic BACHD mouse model [41]. This 24aa peptide, called ED11, was designed on the basis of the caspase- 6 cleavage site in N-terminal part of Htt and was able to inhibit caspase- 6 activity by competing with the caspase- 6 active site on $\mathrm{Htt}$; to enable cell penetration ability, the HIV TAT-derived peptide was used. The authors accurately showed the selective caspase 6 interference effect, with an only minor additional effect on caspase 1 and 10 cleavage sites. Sub-cutaneous continuous administration of ED11 with a minipump at a presymptomatic stage showed restoration of body weight, preserved motor performances, less depressive behaviour and improved cognitive deficits. At a post-symptomatic stage, ED11 administration showed amelioration on motor performances, cognition, and depression. Unfortunately, in this full-length hHtt-97Q transgenic BACHD mouse model, neither aggregation was detectable, nor significant atrophy was found, making impossible the evaluation of the efficacy of the ED11 peptide on these features. Importantly no toxicity in cell or in mouse after prolonged administration was found [41]. 
Table 1 Summary of the efficacy of the different peptides against HD

\begin{tabular}{|c|c|c|c|c|c|c|c|}
\hline Peptide & $\begin{array}{l}\text { Target of the } \\
\text { peptide }\end{array}$ & Model & Population & Way of administration & End point & Method of evaluation & Results \\
\hline \multirow[t]{4}{*}{$\begin{array}{l}\text { Bivalent Htt-binding } \\
\text { peptide (Kazantsev } \\
\text { et al., 2002) [31] }\end{array}$} & \multirow[t]{4}{*}{$\begin{array}{l}\text { PolyQ } \\
\text { stretches }\end{array}$} & Cell culture & cos-1 cells & $\begin{array}{l}\text { Co-transfection of } \mathrm{hHtt}^{17 a a}- \\
103 \mathrm{Q} \pm \text { bivalent } \mathrm{Htt}-\text { binding } \\
\text { peptide }\end{array}$ & Aggregation & $\begin{array}{l}\% \text { of aggregate-positive } \\
\text { transfected cells }\end{array}$ & $\begin{array}{l}\text { Delayed aggregate formation: } \\
37.6 \% \text { reduction at } 48 \text { h; no } \\
\text { reduction at } 96 \mathrm{~h}\end{array}$ \\
\hline & & \multirow[t]{3}{*}{ Drosophila HD } & \multirow{2}{*}{$\begin{array}{l}\text { ELAV-Gal4; UAS- } \\
48 / 108 \mathrm{Q}\end{array}$} & \multirow{2}{*}{$\begin{array}{l}\text { Genetic cross: bivalent } \\
\text { Htt-binding peptide } \\
\text { vs placebo }\end{array}$} & Survival & Survival rate & Significant increased survival \\
\hline & & & & & Aggregation (CNS) & Immunostaining on L3 larvae & Significant aggregate reduction \\
\hline & & & $\begin{array}{l}\text { GMR-Gal4; UAS- } \\
48 / 108 Q\end{array}$ & $\begin{array}{l}\text { Genetic cross: bivalent } \\
\text { Htt-binding peptide } \\
\text { vs placebo }\end{array}$ & $\begin{array}{l}\text { Photoreceptor } \\
\text { neurodegeneration }\end{array}$ & $\begin{array}{l}\text { Quantification of the number } \\
\text { of rhabdomeres/ommatidium }\end{array}$ & $\begin{array}{l}\text { Significant rescue of eye } \\
\text { neurodegeneration }\end{array}$ \\
\hline $\begin{array}{l}\text { Polyglutamine-binding } \\
\text { peptide } 1 \text { (QBP1) } \\
\text { (Nagai et al., 2000) [32] }\end{array}$ & $\begin{array}{l}\text { Expanded } \\
\text { polyQ } \\
\text { stretch }\end{array}$ & Cell culture & cos-7 cells & $\begin{array}{l}\text { Co-transfection of } \\
\text { 45Q-/57Q-/81Q-YFP } \pm \\
\text { QBP1-CFP }\end{array}$ & Aggregation & $\begin{array}{l}\% \text { of aggregate-positive } \\
\text { transfected cells }\end{array}$ & $\begin{array}{l}\text { Significant aggregate reduction, } \\
\text { more important with shorter polyQ }\end{array}$ \\
\hline \multirow[t]{4}{*}{$\begin{array}{l}(\text { QBP1) } 2 \text { (Nagai et al., } \\
\text { 2003) [33] }\end{array}$} & \multirow[t]{4}{*}{$\begin{array}{l}\text { Expanded } \\
\text { polyQ } \\
\text { stretch }\end{array}$} & \multirow[t]{4}{*}{$\begin{array}{l}\text { Drosophila } \\
\text { polyQ models }\end{array}$} & GMR-92Q & $\begin{array}{l}\text { Genetic cross: Eyeless- } \\
\text { Gal4; UAS-(QBP1) } 2 \text { or } \\
\text { GMR-Gal4; UAS-(QBP1) }\end{array}$ & $\begin{array}{l}\text { Photoreceptor } \\
\text { neurodegeneration }\end{array}$ & $\begin{array}{l}\text { Phenotypical comparative } \\
\text { analysis (adult flies) }\end{array}$ & $\begin{array}{l}\text { Significant suppression of eye } \\
\text { degeneration }\end{array}$ \\
\hline & & & $\begin{array}{l}\text { GMR-Gal4; UAS- } \\
\text { MJD't-78Q }\end{array}$ & Genetic cross: UAS-(QBP1) 2 & $\begin{array}{l}\text { Photoreceptor } \\
\text { neurodegeneration }\end{array}$ & $\begin{array}{l}\text { Phenotypical comparative } \\
\text { analysis (adult flies) }\end{array}$ & $\begin{array}{l}\text { Significant suppression of eye } \\
\text { degeneration }\end{array}$ \\
\hline & & & GMR-92Q & $\begin{array}{l}\text { Genetic cross: Eyeless-Gal4; } \\
\text { UAS-(QBP1) }\end{array}$ & $\begin{array}{l}\text { Aggregation in the } \\
\text { eye imaginal disc }\end{array}$ & $\begin{array}{l}\text { Immunostaining (third } \\
\text { instar larvae) }\end{array}$ & $\begin{array}{l}\text { Significant inclusion bodies } \\
\text { reduction }\end{array}$ \\
\hline & & & $\begin{array}{l}\text { ELAV-Gal4; UAS- } \\
\text { MJD'-78Q }\end{array}$ & $\begin{array}{l}\text { Genetic cross: UAS-(QBP1) } \\
\text { or UAS-(scrambled) })_{2}\end{array}$ & Survival & Life span (adult flies) & $\begin{array}{l}\text { Significant increase in survival } \\
\text { (median life span from } 5.5 \text { to } 52 \text { days) }\end{array}$ \\
\hline \multirow[t]{8}{*}{ PTD-QBP1 } & \multirow[t]{8}{*}{$\begin{array}{l}\text { Expanded } \\
\text { polyQ } \\
\text { stretch }\end{array}$} & \multirow[t]{2}{*}{$\begin{array}{l}\text { Cell culture } \\
\text { (Popiel et al., } \\
\text { 2007) [39] }\end{array}$} & cos-7 cells & $\begin{array}{l}\text { Co-transfection of } 81 \mathrm{Q}-\mathrm{GFP} \pm \\
\text { Antp-QBP1 provided in the } \\
\text { cell medium }\end{array}$ & Aggregation & $\begin{array}{l}\% \text { of transfected cells forming } \\
\text { inclusion bodies }\end{array}$ & $\begin{array}{l}\text { Significant reduction (from } 42 \% \\
\text { to } 30 \% \text { ) }\end{array}$ \\
\hline & & & cos-7 cells & $\begin{array}{l}\text { Co-transfection of } 57 \mathrm{Q}-\mathrm{GFP} \pm \\
\text { TAT-QBP1 provided in the } \\
\text { cell medium }\end{array}$ & Cell survival & Quantification of cell death & $\begin{array}{l}\text { Significant reduction of cell death } \\
\text { (from } 11.8 \% \text { to } 7.4 \% \text { ) }\end{array}$ \\
\hline & & \multirow{2}{*}{$\begin{array}{l}\text { Drosophila } \\
\text { polyQ model } \\
\text { (Popiel et al.., } \\
\text { 2007) [39] }\end{array}$} & \multirow[t]{2}{*}{ 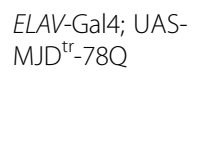 } & \multirow[t]{2}{*}{$\begin{array}{l}\text { Oral administration of } \\
\text { Antp-QBP1 }\end{array}$} & Survival & Survival rate (5,10, and 15 days) & Significant increase \\
\hline & & & & & $\begin{array}{l}\text { Aggregation in the } \\
\text { eye imaginal disc }\end{array}$ & $\begin{array}{l}\text { Immunostaining (third } \\
\text { instar larvae) }\end{array}$ & $\begin{array}{l}\text { Significant reduction of inclusion } \\
\text { bodies }\end{array}$ \\
\hline & & \multirow{4}{*}{$\begin{array}{l}\text { Mouse model } \\
\text { (Popiel et al., } \\
\text { 2009) [40] }\end{array}$} & \multirow[t]{4}{*}{ R6/2 mice } & \multirow{3}{*}{$\begin{array}{l}\text { Long-term continuous } \\
\text { intraperitoneal administration } \\
\text { of either Antp-QBP1 ( } 2 \mathrm{mg} / \text { week) } \\
\text { or saline from wk2 }\end{array}$} & $\begin{array}{l}\text { Motor } \\
\text { performances }\end{array}$ & $\begin{array}{l}\text { Latency to fall with accelerating } \\
\text { rotarod (from wk5 to death) }\end{array}$ & No significant difference \\
\hline & & & & & Body weight & $\begin{array}{l}\text { Weight measure (from wk5 } \\
\text { to death) }\end{array}$ & $\begin{array}{l}\text { Significant weight increased } \\
\text { compared to saline-treated mice } \\
\text { from wk5 to } 10\end{array}$ \\
\hline & & & & & Survival & Life span & No significant difference \\
\hline & & & & $\begin{array}{l}\text { Long-term continuous } \\
\text { intraperitoneal administration } \\
\text { of either Antp-QBP1 ( } 2 \mathrm{mg} / \text { week) } \\
\text { or saline from wk2 }\end{array}$ & Aggregation & $\begin{array}{l}\text { Brain section immunostaining } \\
\text { with anti-htt antibody }\end{array}$ & No significant difference \\
\hline
\end{tabular}


Table 1 Summary of the efficacy of the different peptides against HD (Continued)

\begin{tabular}{|c|c|c|c|c|c|c|c|}
\hline \multirow[t]{11}{*}{$\begin{array}{l}\text { ED11 (Aharony } \\
\text { et al., 2015) [41] }\end{array}$} & \multirow[t]{11}{*}{$\begin{array}{l}\text { Inhibitor of } \\
\text { caspase-6 }\end{array}$} & Cell culture & PC12 cells & $\begin{array}{l}\text { Inducible mHtt- } 145 \mathrm{Q} \pm \mathrm{TAT}-\mathrm{ED} 11 \\
\text { provided in the cell medium }\end{array}$ & Survival & $\begin{array}{l}\text { Cell viability and cell death } \\
\text { assessment }\end{array}$ & $\begin{array}{l}\text { Significant increased cell viability } \\
\text { and decreased cell death }\end{array}$ \\
\hline & & \multirow[t]{10}{*}{ Mouse model } & \multirow{10}{*}{$\begin{array}{l}\text { Full-length } \\
\text { hHtt-97Q } \\
\text { BACHD }\end{array}$} & \multirow{6}{*}{$\begin{array}{l}\text { Pre-symptomatic treatment } \\
\text { (from wk5); continuous infusion } \\
\text { ( } 4 \mathrm{mg} / \mathrm{kg} / \mathrm{day} \text {; subcutaneously } \\
\text { implanted mini-pump) of ED } 11 \\
\text { peptide vs vehicle in BACHD } \\
\text { mice and of vehicle in wt mice }\end{array}$} & $\begin{array}{l}\text { Body weight } \\
\text { (excessive weight) }\end{array}$ & Weight measure & Attenuation of weight gain \\
\hline & & & & & $\begin{array}{l}\text { Motor } \\
\text { performances }\end{array}$ & $\begin{array}{l}\text { Latency to fall with accelerating } \\
\text { rotarod (monthly from wk9) }\end{array}$ & $\begin{array}{l}\text { Preserved motor performance } \\
\text { compared to wt mice. }\end{array}$ \\
\hline & & & & & $\begin{array}{l}\text { Depressive-like } \\
\text { behaviour }\end{array}$ & $\begin{array}{l}\text { Immobility evaluation during } \\
\text { the forced swim test (FST) } \\
\text { ( } 5 \text { months of age) }\end{array}$ & Prevention of increased immobility \\
\hline & & & & & $\begin{array}{l}\text { Basal locomotor } \\
\text { activity, exploratory } \\
\text { activity, anxiety- } \\
\text { related behaviour }\end{array}$ & $\begin{array}{l}\text { Open field test (wk22): total } \\
\text { travelled distance; time spent } \\
\text { in the centre and number of } \\
\text { transitions to the centre }\end{array}$ & $\begin{array}{l}\text { Unchanged basal locomotor } \\
\text { activity; lower anxiety levels and } \\
\text { improved exploratory behaviour in } \\
\text { treated vs untreated mice }\end{array}$ \\
\hline & & & & & $\begin{array}{l}\text { Inhibition of } \\
\text { caspase- } 6 \text { activity }\end{array}$ & $\begin{array}{l}\text { Quantification of } \mathrm{mHtt} \mathrm{Ht}^{586 a} \\
\text { fragments (6-month-old mice) }\end{array}$ & $\begin{array}{l}\text { Not evaluable (no detectable } \\
\mathrm{mH} \mathrm{Ht}^{856 a} \text { fragments in } \\
\text { untreated mice) }\end{array}$ \\
\hline & & & & & Aggregation & $\begin{array}{l}\text { Immunostaining (6-month- } \\
\text { old mice) }\end{array}$ & $\begin{array}{l}\text { Not evaluable (no detectable } \\
\text { aggregates in untreated mice) }\end{array}$ \\
\hline & & & & \multirow{4}{*}{$\begin{array}{l}\text { Post-symptomatic treatment } \\
\text { (from w36); continuous infusion } \\
(4 \mathrm{mg} / \mathrm{kg} / \mathrm{day} ; \text { subcutaneously } \\
\text { implanted mini-pump) of ED } 11 \\
\text { peptide vs vehicle in BACHD } \\
\text { mice and of vehicle in wt mice }\end{array}$} & $\begin{array}{l}\text { Motor } \\
\text { performances }\end{array}$ & $\begin{array}{l}\text { Latency to fall with accelerating } \\
\text { rotarod (monthly, wk30 to } 44 \text { ) }\end{array}$ & $\begin{array}{l}\text { Increased motor performance } \\
\text { compared to untreated mice }\end{array}$ \\
\hline & & & & & $\begin{array}{l}\text { Depressive-like } \\
\text { behaviour }\end{array}$ & $\begin{array}{l}\text { Immobility evaluation during } \\
\text { the forced swim test (FST) } \\
\text { (11 months of age) }\end{array}$ & Rescue at the level of wt littermates \\
\hline & & & & & Cognitive deficits & $\begin{array}{l}\text { Swimming T-maze test; shifting } \\
\text { abilities (time to reach the } \\
\text { re-located hidden platform) }\end{array}$ & Rescue at the level of wt littermates \\
\hline & & & & & Brain atrophy & $\begin{array}{l}\text { MRI volumetric measurements } \\
\text { (12 months of age) }\end{array}$ & $\begin{array}{l}\text { Not evaluable (no significant } \\
\text { atrophy in untreated BACHD mice) }\end{array}$ \\
\hline
\end{tabular}

\section{as a number $\mathrm{Y}$ of $\mathrm{Q}$.}


Table 2 Summary of the efficacy of the different intrabodies against HD

\begin{tabular}{|c|c|c|c|c|c|c|c|}
\hline Antibody & $\begin{array}{l}\text { Target of } \\
\text { the peptide }\end{array}$ & Model & Population & Way of administration & End point & Method of evaluation & Results \\
\hline \multirow[t]{6}{*}{ C4 intrabody } & $\begin{array}{l}\mathrm{N} 17 \\
\text { terminal } \\
\text { region }\end{array}$ & $\begin{array}{l}\text { Cell culture (Lecerf } \\
\text { et al., 2001) [44] }\end{array}$ & $\begin{array}{l}\text { COS-7; BHK-21; } \\
\text { HEK293 }\end{array}$ & $\begin{array}{l}\text { Co-transfection: } \mathrm{hHtt}^{17 a a} \\
\text {-25/73/103Q-GPP } \pm \text { C4 } \\
\text { intrabody (ratio 5:1) }\end{array}$ & Aggregation & $\begin{array}{l}\% \text { of aggregate-positive } \\
\text { transfected cells }\end{array}$ & Reduction up to $86 \%$ \\
\hline & & $\begin{array}{l}\text { Organotypic cultures } \\
\text { (Murphy and Messer, } \\
\text { 2004) [46] }\end{array}$ & $\begin{array}{l}\text { Cortico-striatal } \\
\text { slice cultures }\end{array}$ & $\begin{array}{l}\text { Malonate treatment, and } \\
\text { transfection with } \mathrm{hHtt}^{17 \mathrm{aa}} \\
-25 / 72 \mathrm{Q}-\mathrm{GFP} \pm \mathrm{C} 4 \text { intrabody }\end{array}$ & Cell survival & $\begin{array}{l}\% \text { of co-transfected died or } \\
\text { dying cells }\end{array}$ & Rescue to wt level \\
\hline & & $\begin{array}{l}\text { Drosophila model } \\
\text { (Wolfgang et al., 2005) [45] }\end{array}$ & $\begin{array}{l}\text { ELAV-Gal4; } \\
\text { UAS-hHttex } \\
\text { 20/93Q; }\end{array}$ & $\begin{array}{l}\text { Genetic cross: UAS-C4 } \\
\text { intrabody" }\end{array}$ & Survival & $\begin{array}{l}\% \text { of survival to adult (eclosion); } \\
\text { mean, median, and maximal } \\
\text { lifespan }\end{array}$ & $\begin{array}{l}\text { Increased survival to } \\
\text { adulthood (from } 23 \% \text { to } \\
100 \% \text { ); increased mean } \\
\text { adult lifespan by } 30-50 \%\end{array}$ \\
\hline & & & & & $\begin{array}{l}\text { Aggregation; } \\
\text { quantification of } \\
\text { soluble polyQ forms }\end{array}$ & $\begin{array}{l}\text { Immunostaining; detergent- } \\
\text { soluble } \mathrm{hHtt} \mathrm{Ht}^{\mathrm{ex}}-93 \mathrm{Q} \text { detection } \\
\text { (Western blot) }\end{array}$ & $\begin{array}{l}\text { Slowing of visible } \\
\text { aggregate formation. } \\
\text { Increased levels of } \\
\text { soluble Htt }\end{array}$ \\
\hline & & & & & Neurodegeneration & $\begin{array}{l}\text { Photoreceptors/ommatidium } \\
\text { quantification }\end{array}$ & $\begin{array}{l}\text { Slowing of } \\
\text { neurodegeneration in } \\
\text { photoreceptors cells }\end{array}$ \\
\hline & & $\begin{array}{l}\text { Mouse model (Snyder-Keller } \\
\text { et al., 2010) [47] }\end{array}$ & $\begin{array}{l}\text { B6.HD6/1 125Q } \\
\left.\text { (hHtt }{ }^{\mathrm{ex}}-125 \mathrm{Q}\right)\end{array}$ & $\begin{array}{l}\text { C4 intrabody with AAV vector } \\
\text { into the striatum; presymptomatic } \\
\text { (injection: wk5 to } 8 \text {; killed at } \\
\text { wk16 to } 32 \text { ); symptomatic (injection } \\
\text { wk } 10 \text { to 24; killed } 8 \text { to } 10 \text { wk later) }\end{array}$ & Aggregation & $\begin{array}{l}\text { Immunostainig: number and } \\
\text { size aggregates }\end{array}$ & $\begin{array}{l}\text { Pre-symptomatic and } \\
\text { symptomatic effect: } \\
\text { aggregate reduction } \\
\text { (size > number), more } \\
\text { important in pre- } \\
\text { symptomatically treated } \\
\text { mice }\end{array}$ \\
\hline \multirow[t]{7}{*}{$\begin{array}{l}V_{L} 12.3 \\
\text { intrabody }\end{array}$} & $\begin{array}{l}\mathrm{N} 17 \\
\text { terminal } \\
\text { region }\end{array}$ & $\begin{array}{l}\text { Cell culture (Colby et al., } \\
\text { 2004) [48] }\end{array}$ & HEK293 & $\begin{array}{l}\text { Co-tranfection: } \mathrm{hHtt}^{\mathrm{ex} 1} \text {-97Q-GFP + } \\
\text { empty vector or } \mathrm{V}_{\mathrm{L}} 12.3\end{array}$ & Aggregation & Immunostaining & $\begin{array}{l}50 \% \text { reduction of } \\
\text { aggregates vs empty } \\
\text { vector }\end{array}$ \\
\hline & & $\begin{array}{l}\text { Cell culture } \\
\text { (Southwell et al., 2008) [49] }\end{array}$ & HEK293 & $\begin{array}{l}\text { Co-transfection: } \mathrm{hHtt}^{\mathrm{ex} 1}-103 \mathrm{Q}-\mathrm{GFP}+ \\
\text { empty vector or } \mathrm{V}_{\mathrm{L}} 12.3\end{array}$ & Aggregation & Immunostaining & $\begin{array}{l}\text { Dose-dependent } \\
\text { aggregate reduction }\end{array}$ \\
\hline & & & & & Cell survival & $\%$ of co-transfected dead cells & Reduced cell toxicity \\
\hline & & & & $\begin{array}{l}\text { Co-transfection: hHtt }{ }^{\mathrm{ex}}-25 / 103 \mathrm{Q}- \\
\mathrm{GFP}+\mathrm{V}_{\mathrm{L}} 12.3\end{array}$ & $\begin{array}{l}\text { Quantification of } \\
\text { soluble and } \\
\text { insoluble } \mathrm{hHtt}^{\mathrm{e} \times 1}\end{array}$ & $\begin{array}{l}\text { Centrifugation and Immunoblot } \\
\text { assay }\end{array}$ & $\begin{array}{l}\text { Significant reduction of } \\
\text { insoluble but not of } \\
\text { soluble } h \mathrm{Htt}^{\mathrm{e} \times 1}-103 \mathrm{Q} \\
\text { levels }\end{array}$ \\
\hline & & & & $\begin{array}{l}\text { Co-transfection: } \mathrm{hHtt}{ }^{\mathrm{ex}}-103 \mathrm{Q} \\
\text {-SNAP tag } \pm \mathrm{V}_{\mathrm{L}} 12.3\end{array}$ & $\begin{array}{l}\mathrm{hH} \mathrm{tt}^{\mathrm{e} \times 1}-103 \mathrm{Q} \\
\text { turnover }\end{array}$ & Fluorescence intensity of SNAP-tag & $\begin{array}{l}\text { No effect on polyQ } \\
\text { turnover }\end{array}$ \\
\hline & & $\begin{array}{l}\text { Cortico-striatal brain slice } \\
\text { model (Southwell et al., } \\
\text { 2008) [49] }\end{array}$ & Rat brain slices & $\begin{array}{l}\text { Co-transfection: YFP as } \\
\text { morphometric marker } \pm \mathrm{hHtt}{ }^{\mathrm{ex} 1} \\
-103 \mathrm{Q}-\mathrm{CFP} \pm \mathrm{V}_{\mathrm{L}} 12.3\end{array}$ & Neurodegeneration & $\begin{array}{l}\text { Immunostaining: counting of } \\
\text { healthy striatal medium spiny } \\
\text { neurons (MSNs) }\end{array}$ & $\begin{array}{l}\text { Rescue of } \\
\text { neurodegeneration at the } \\
\text { level of wt cells }\end{array}$ \\
\hline & & & $\begin{array}{l}\text { ST14A striatal } \\
\text { precursor cells }\end{array}$ & $\begin{array}{l}\text { Co-transfection: } \mathrm{hHtt}{ }^{\mathrm{ex} 1}-103 \mathrm{Q} \\
-\mathrm{GFP} \pm \mathrm{V}_{\mathrm{L}} 12.3\end{array}$ & $\begin{array}{l}\mathrm{hHtt} \mathrm{t}^{\mathrm{ex}}-103 \mathrm{Q} \\
\text { localisation and } \\
\text { turnover }\end{array}$ & $\begin{array}{l}\text { Immunostaining: cytoplasmic/ } \\
\text { nuclear } \mathrm{hHtt}^{\mathrm{ex}}-103 \mathrm{Q} \text { ratio }\end{array}$ & $\begin{array}{l}\text { Altered cytoplasmic/ } \\
\text { nuclear trafficking: } \\
\text { significant increase of } \\
\text { nuclear Htt }\end{array}$ \\
\hline
\end{tabular}


Table 2 Summary of the efficacy of the different intrabodies against HD (Continued)

\begin{tabular}{|c|c|c|c|c|c|}
\hline \multirow[t]{15}{*}{$\begin{array}{l}\text { Mouse model (Southwell } \\
\text { et al., 2009) [51] }\end{array}$} & \multirow[t]{3}{*}{$\begin{array}{l}\text { C57BL/6 } \\
\text { (lentiviral HD } \\
\text { model) }\end{array}$} & \multirow[t]{3}{*}{$\begin{array}{l}\text { HD model: Unilateral striatal } \\
\text { injection: } h \mathrm{hHtt}^{\mathrm{ex} 1}-103 \mathrm{Q}-\mathrm{GFP} \text { or } \\
\text { GFP lentivirus. } \\
\text { Treatment: }+\mathrm{V}_{\mathrm{L}} 12.3-\mathrm{AAV} \text { or } \\
\text { GFP (4 wk-old mice). Tests } \\
\text { 6wks later. }\end{array}$} & $\begin{array}{l}\text { Amphetamine- } \\
\text { induced rotation }\end{array}$ & $\begin{array}{l}\text { Ipsilateral rotations tested during } \\
30^{\prime} \text { after intraperitoneal } \\
\text { amphetamine injection. }\end{array}$ & $\begin{array}{l}\text { Strong reduction of the } \\
\text { number of ipsilateral } \\
\text { rotations to the levels of } \\
\text { GFP lentivirus injected } \\
\text { animals }\end{array}$ \\
\hline & & & MSNs loss & DARPP-32 staining & $\begin{array}{l}\text { Rescue to the levels of } \\
\text { GFP lentivirus injected } \\
\text { animals }\end{array}$ \\
\hline & & & Aggregation & $\begin{array}{l}\text { Striatal immunostaining with } \\
\text { anti-Htt MW8 (detect } \\
\text { aggregates only) }\end{array}$ & $\begin{array}{l}\text { Significant aggregate } \\
\text { reduction vs AAV-GFP } \\
\text { injected animals }\end{array}$ \\
\hline & \multirow{7}{*}{$\begin{array}{l}\text { YAC128 (Full } \\
\text { length-hHtt- } \\
\text { 128Q) }\end{array}$} & \multirow{7}{*}{$\begin{array}{l}\text { 2-months-old male mice and wt } \\
\text { littermates injected bilaterally in } \\
\text { the striatum with GFP- or } V_{L} \\
\text { 12.3- AAV }\end{array}$} & \multirow[t]{3}{*}{$\begin{array}{l}\text { Motor } \\
\text { performances }\end{array}$} & $\begin{array}{l}\text { Rotarod latency to fall (monthly } \\
\text { from } 3 \text { to } 7 \text { months of age) }\end{array}$ & No effect \\
\hline & & & & $\begin{array}{l}\text { Beam-crossing performance } \\
\text { (monthly from } 3 \text { to } 7 \text { months } \\
\text { of age) }\end{array}$ & No effect \\
\hline & & & & $\begin{array}{l}\text { Climbing time (7-month-old } \\
\text { mice) }\end{array}$ & No effect \\
\hline & & & $\begin{array}{l}\text { Cognitive } \\
\text { performances } \\
\text { (spatial and } \\
\text { cortical learning) }\end{array}$ & $\begin{array}{l}\text { Novel object location and } \\
\text { novel object preference tests } \\
\text { (7-month-old mice) }\end{array}$ & No effect in both tests \\
\hline & & & Anxiety & Open field test & $\begin{array}{l}\text { Non significant } \\
\text { amelioration }\end{array}$ \\
\hline & & & Brain atrophy & $\begin{array}{l}\text { Ventricular size assessment } \\
\text { (7-month-old mice) }\end{array}$ & No effect \\
\hline & & & Body weight & $\begin{array}{l}\text { Assessment monthly from } 3 \\
\text { to } 7 \text { months of age }\end{array}$ & No effect \\
\hline & \multirow[t]{5}{*}{$\begin{array}{l}\text { R6/2 (hhtt }{ }^{\mathrm{ex}} \text { - } \\
\text { 144Q) }\end{array}$} & \multirow{5}{*}{$\begin{array}{l}\text { 3-day-old male mice and wt } \\
\text { littermates: bilateral injection } \\
\text { at the center of each forebrain } \\
\text { hemisphere of GFP- or } V_{L} 12.3-A A V\end{array}$} & \multirow[t]{2}{*}{$\begin{array}{l}\text { Motor } \\
\text { performances }\end{array}$} & $\begin{array}{l}\text { Rotarod latency to fall (weekly } \\
\text { from w4 to death) }\end{array}$ & $\begin{array}{l}\text { Reduced latency to fall } \\
\text { (wk } 10 \text { to 12) }\end{array}$ \\
\hline & & & & $\begin{array}{l}\text { Beam-crossing performance } \\
\text { (weekly from w4 to death) }\end{array}$ & $\begin{array}{l}\text { No rescue: Increased } \\
\text { severity of the phenotype } \\
\text { (time to cross the beam) }\end{array}$ \\
\hline & & & Brain atrophy & $\begin{array}{l}\text { Ventricular size assessment } \\
\text { (10-wk-old mice) }\end{array}$ & No effect \\
\hline & & & Body weight & $\begin{array}{l}\text { Assessment weekly from } \\
4 \text { wk until death }\end{array}$ & No effect \\
\hline & & & Aggregation & $\begin{array}{l}\text { Striatal immunostaining with } \\
\text { anti-Htt MW8 (detect aggregates } \\
\text { only) and nuclear marker; counting } \\
\text { of positive foci ( } 10 \text { week-old mice) }\end{array}$ & $\begin{array}{l}\text { Reduction of the number } \\
\text { of neuropil aggregates; } \\
\text { no significant reduction } \\
\text { of intranuclear } \\
\text { aggregates }\end{array}$ \\
\hline
\end{tabular}


Table 2 Summary of the efficacy of the different intrabodies against HD (Continued)

\begin{tabular}{|c|c|c|c|c|c|c|c|}
\hline & & & & & Life span & $\begin{array}{l}\text { Once ill, twice a day assessment } \\
\text { of righting reflex }\end{array}$ & $\begin{array}{l}\text { Aggravation and } \\
\text { decrease survival }\end{array}$ \\
\hline \multirow[t]{8}{*}{$\begin{array}{l}\text { MW7 } \\
\text { intrabody }\end{array}$} & \multirow[t]{8}{*}{$\begin{array}{l}\text { Poly } P \\
\text { region }\end{array}$} & \multirow[t]{2}{*}{$\begin{array}{l}\text { Cell culture (Khoshnan } \\
\text { et al., 2002) [50] }\end{array}$} & \multirow[t]{2}{*}{ HEK293 } & \multirow[t]{2}{*}{$\begin{array}{l}\text { Co-transfection: } \mathrm{hHtt}^{\mathrm{e} \times 1}-97 \mathrm{Q}-\mathrm{GFP} \\
\text { and MW7 or empty vector }\end{array}$} & $\begin{array}{l}\text { Aggregated/ } \\
\text { soluble Htt }\end{array}$ & $\begin{array}{l}\text { Centrifugation, SDS treatment } \\
\text { and western blotting }\end{array}$ & $\begin{array}{l}\text { Reduction of both } \\
\text { aggregated and soluble } \\
\text { polyQHtt }\end{array}$ \\
\hline & & & & & Cell survival & TUNEL staining & $\begin{array}{l}33 \% \text { reduction of TUNEL } \\
\text { positive cells }\end{array}$ \\
\hline & & \multirow[t]{4}{*}{$\begin{array}{l}\text { Cell culture (Southwell } \\
\text { et al., 2008) [49] }\end{array}$} & \multirow[t]{4}{*}{ HEK293 } & $\begin{array}{l}\text { Co-transfection: hHtt }{ }^{\mathrm{ex}}-103 \mathrm{Q}- \\
\text { GFP + empty vector or MW7 }\end{array}$ & Aggregation & Immunostaining & $\begin{array}{l}\text { Aggregate reduction with } \\
\text { a threshold-effect }\end{array}$ \\
\hline & & & & & Cell survival & $\%$ of co-transfected dead cells & Reduced cell toxicity \\
\hline & & & & $\begin{array}{l}\text { Co-transfection: hHtte }{ }^{\mathrm{ex}}-25 / \\
\text { 103Q-GFP + MW7 }\end{array}$ & $\begin{array}{l}\text { Quantification of } \\
\text { soluble and } \\
\text { insoluble } \mathrm{hHtt} \mathrm{te}^{\mathrm{x}}\end{array}$ & $\begin{array}{l}\text { Centrifugation and Immunoblot } \\
\text { essay }\end{array}$ & $\begin{array}{l}\text { Significant reduction of } \\
\text { both soluble and } \\
\text { insoluble } \mathrm{hH} \mathrm{tt}^{\mathrm{ex}}-103 \mathrm{Q} \\
\text { no effect on soluble wt } \\
\mathrm{hH} \mathrm{tt}^{\mathrm{ex} 1}-25 \mathrm{Q}\end{array}$ \\
\hline & & & & $\begin{array}{l}\text { Co-transfection: } h \mathrm{hHtt}^{\mathrm{ex} 1}-103 \mathrm{Q} \\
- \text { SNAP tag } \pm \mathrm{MW} 7\end{array}$ & $\begin{array}{l}\mathrm{hH} \mathrm{tt}^{\mathrm{ex}}-103 \mathrm{Q} \\
\text { turnover }\end{array}$ & $\begin{array}{l}\text { Fluorescence intensity of SNAP } \\
\text { tag }\end{array}$ & $\begin{array}{l}\text { Significant decreased } \\
\text { fluorescence (increased } \\
\mathrm{hH} H \mathrm{tt}^{\mathrm{e} \times 1}-103 \mathrm{Q} \text { turnover) }\end{array}$ \\
\hline & & \multirow{2}{*}{$\begin{array}{l}\text { Cortico-striatal } \\
\text { brain slice model } \\
\text { (Southwell et al., 2008) [49] }\end{array}$} & Rat brain slices & $\begin{array}{l}\text { Co-transfection: YFP } \pm \mathrm{hH} \mathrm{tt}^{\mathrm{ex}} \\
-103 \mathrm{Q}-\mathrm{CFP} \pm \mathrm{MW} 7\end{array}$ & Neurodegeneration & $\begin{array}{l}\text { Immunostaining: counting of } \\
\text { healthy MSNs }\end{array}$ & $\begin{array}{l}\text { Non-significant reduction } \\
\text { of neurodegeneration }\end{array}$ \\
\hline & & & $\begin{array}{l}\text { ST14A striatal } \\
\text { precursor }\end{array}$ & $\begin{array}{l}\text { Co-transfection: hHttt }{ }^{\mathrm{ex}}-103 \mathrm{Q} \\
-\mathrm{GFP} \pm \mathrm{MW} 7\end{array}$ & $\begin{array}{l}\mathrm{hH} \mathrm{tt}^{\mathrm{e} \times 1}-103 \mathrm{Q} \\
\text { localisation and } \\
\text { turnover }\end{array}$ & $\begin{array}{l}\text { Immunostaining: cytoplasmic/ } \\
\text { nuclear } \mathrm{hHtt} \text { ex1 }-103 \mathrm{Q} \text { ratio }\end{array}$ & No effect \\
\hline \multirow[t]{6}{*}{$\begin{array}{l}\text { Happ1-Happ3 } \\
\text { antibodies }\end{array}$} & \multirow[t]{6}{*}{$\begin{array}{l}\text { Poly } P \\
\text { region }\end{array}$} & \multirow[t]{4}{*}{$\begin{array}{l}\text { Cell culture (Southwell } \\
\text { 2008) [49] }\end{array}$} & \multirow[t]{4}{*}{ HEK293 } & \multirow[t]{2}{*}{$\begin{array}{l}\text { Co-transfection: } \mathrm{hHtt} \\
\text { + empty vector or } \mathrm{Happ} 1 \text {-Happ3 }\end{array}$} & Aggregation & Immunostaining & $\begin{array}{l}\text { Dose-dependent } \\
\text { aggregate reduction }\end{array}$ \\
\hline & & & & & Cell survival & $\%$ of co-transfected dead cells & Reduced cell toxicity \\
\hline & & & & $\begin{array}{l}\text { Co-transfection: hHttex1-25/103Q } \\
\text {-GFP + Happ1-Happ3 }\end{array}$ & $\begin{array}{l}\text { Quantification of } \\
\text { soluble and } \\
\text { insoluble } \mathrm{hH} \mathrm{tt}^{\mathrm{ex}}\end{array}$ & $\begin{array}{l}\text { Centrifugation and Immunoblot } \\
\text { essay }\end{array}$ & 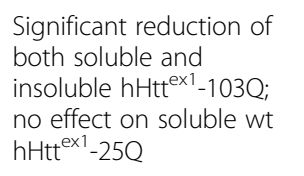 \\
\hline & & & & $\begin{array}{l}\text { Co-transfection: hHtt }{ }^{\mathrm{ex} 1}-103 \mathrm{Q} \\
\text {-SNAP tag } \pm \text { Happ1-Happ3 }\end{array}$ & $\begin{array}{l}\mathrm{hH} \mathrm{tt}^{\mathrm{ex}}-103 \mathrm{Q} \\
\text { turnover }\end{array}$ & $\begin{array}{l}\text { Fluorescence intensity of SNAP } \\
\text { tag }\end{array}$ & 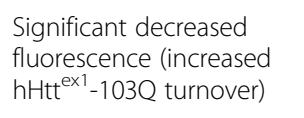 \\
\hline & & \multirow[t]{2}{*}{$\begin{array}{l}\text { Cortico-striatal brain slice } \\
\text { model (Southwell et al., } \\
\text { 2008) [49] }\end{array}$} & Rat brain slices & $\begin{array}{l}\text { Co-transfection: YFP as } \\
\text { morphometric marker } \pm \mathrm{hH} \mathrm{ttt}^{\mathrm{ex} 1} \\
-103 \mathrm{Q}-\mathrm{CFP} \pm \mathrm{Happ} 1-\mathrm{Happ} 3\end{array}$ & Neurodegeneration & $\begin{array}{l}\text { Immunostaining: counting of } \\
\text { MSNs }\end{array}$ & $\begin{array}{l}\text { Significant reduction of } \\
\text { neurodegeneration }\end{array}$ \\
\hline & & & $\begin{array}{l}\text { ST14A striatal } \\
\text { precursor }\end{array}$ & $\begin{array}{l}\text { Co-transfection: hHtt }{ }^{\mathrm{ex} 1}-103 \mathrm{Q} \\
-\mathrm{GFP} \pm \text { Happ1-Happ3 }\end{array}$ & $\begin{array}{l}\mathrm{hH} \mathrm{Htt}^{\mathrm{ex}}-103 \mathrm{Q} \\
\text { localisation and } \\
\text { turnover }\end{array}$ & $\begin{array}{l}\text { Immunostaining: cytoplasmic/ } \\
\text { nuclear } \mathrm{hHtt}^{\mathrm{ex}}-103 \mathrm{Q} \text { ratio }\end{array}$ & No effect \\
\hline
\end{tabular}


Table 2 Summary of the efficacy of the different intrabodies against HD (Continued)

\begin{tabular}{|c|c|c|c|c|c|}
\hline \multirow[t]{13}{*}{$\begin{array}{l}\text { Mouse model (Southwell } \\
\text { et al., 2009) [51] }\end{array}$} & \multirow[t]{3}{*}{$\begin{array}{l}\text { C57BL/6 } \\
\text { (lentiviral HD } \\
\text { model) }\end{array}$} & \multirow[t]{3}{*}{$\begin{array}{l}\text { HD model: Unilateral striatal } \\
\text { injection: } \mathrm{hHtt \textrm {e } \times 1} \text {-103Q -GFP } \\
\text { or GFP lentivirus. } \\
\text { Treatment: + GFP- or Happ1- } \\
\text { AAV (4 wk-old mice). Tests } \\
\text { 6wks later. }\end{array}$} & $\begin{array}{l}\text { Amphetamine- } \\
\text { induced rotation, }\end{array}$ & $\begin{array}{l}\text { Ipsilateral rotations tested during } \\
30^{\prime} \text { after intraperitoneal } \\
\text { amphetamine injection. }\end{array}$ & $\begin{array}{l}\text { Strong reduction of the } \\
\text { number of ipsilateral } \\
\text { rotations to the levels of } \\
\text { GFP lentivirus injected } \\
\text { animals }\end{array}$ \\
\hline & & & MSNs loss & DARPP-32 staining & $\begin{array}{l}\text { Rescue to the levels of } \\
\text { GFP lentivirus injected } \\
\text { animals }\end{array}$ \\
\hline & & & Aggregation & $\begin{array}{l}\text { Striatal immunostaining with anti- } \\
\text { Htt MW8 (detect aggregates only) } \\
\text { and nuclear marker; counting of } \\
\text { positive foci. }\end{array}$ & $\begin{array}{l}\text { Significant aggregate } \\
\text { reduction vs AAV-GFP } \\
\text { injected animals }\end{array}$ \\
\hline & \multirow{7}{*}{$\begin{array}{l}\text { YAC128 (Full } \\
\text { length-hHtt- } \\
\text { 128Q) }\end{array}$} & \multirow{7}{*}{$\begin{array}{l}\text { 2-months-old male mice and } \\
\text { wt littermates injected bilaterally } \\
\text { in the striatum with GFP- or } \\
\text { Happ1- AAV }\end{array}$} & \multirow[t]{3}{*}{$\begin{array}{l}\text { Motor } \\
\text { performances }\end{array}$} & $\begin{array}{l}\text { Rotarod latency to fall (monthly } \\
\text { from } 3 \text { to } 7 \text { months of age) }\end{array}$ & $\begin{array}{l}\text { Improvement in 3-, 4-, } \\
\text { and } 7 \text {-month-old mice }\end{array}$ \\
\hline & & & & $\begin{array}{l}\text { Beam-crossing performance } \\
\text { (monthly from } 3 \text { to } 7 \text { months } \\
\text { of age) }\end{array}$ & Partial improvement \\
\hline & & & & Climbing (7-month-old mice) & $\begin{array}{l}\text { Increased climbing time } \\
\text { to the level of wt } \\
\text { littermates }\end{array}$ \\
\hline & & & $\begin{array}{l}\text { Cognitive } \\
\text { performances } \\
\text { (spatial and cortical } \\
\text { learning) }\end{array}$ & $\begin{array}{l}\text { Novel object location and novel } \\
\text { object preference tests } \\
\text { (7-month-old mice) }\end{array}$ & $\begin{array}{l}\text { Significant amelioration } \\
\text { of spatial and cortical } \\
\text { learning }\end{array}$ \\
\hline & & & Anxiety & Open field test & $\begin{array}{l}\text { Rescue to the level of wt } \\
\text { littermates }\end{array}$ \\
\hline & & & Brain atrophy & $\begin{array}{l}\text { Ventricular size assessment } \\
\text { (7-month-old mice) }\end{array}$ & $\begin{array}{l}\text { Reduction of ventricular } \\
\text { size }\end{array}$ \\
\hline & & & Body weight & $\begin{array}{l}\text { Assessment monthly from } 3 \\
\text { to } 7 \text { months of age }\end{array}$ & No effect \\
\hline & \multirow[t]{3}{*}{$\begin{array}{l}\text { R6/2 (hhtt }{ }^{\mathrm{ex}}- \\
144 \mathrm{Q})\end{array}$} & \multirow{3}{*}{$\begin{array}{l}\text { 3-day-old male mice and wt } \\
\text { littermates: bilateral injection } \\
\text { at the center of each forebrain } \\
\text { hemisphere of GFP- or Happ-AAV }\end{array}$} & \multirow[t]{2}{*}{$\begin{array}{l}\text { Motor } \\
\text { performances }\end{array}$} & $\begin{array}{l}\text { Rotarod latency to fall (weekly } \\
\text { from } 4 \text { wk until death) }\end{array}$ & $\begin{array}{l}\text { Amelioration (between } \\
\text { W9 and } 12 \text { of age) vs } \\
\text { GFP-AW injected animals. }\end{array}$ \\
\hline & & & & $\begin{array}{l}\text { Beam-crossing performance } \\
\text { (weekly from } 4 \text { wk until death) }\end{array}$ & $\begin{array}{l}\text { Reduction of the time to } \\
\text { cross the } 12 \mathrm{~mm} \text { beam in } \\
10 \text { - and } 11 \text {-week-old } \\
\text { mice, and the } 6 \mathrm{~mm} \\
\text { beam between } 9 \text { and } \\
11 \text { weeks of age }\end{array}$ \\
\hline & & & Brain atrophy & $\begin{array}{l}\text { Ventricular size assessment } \\
\text { (10-wk-old mice) }\end{array}$ & $\begin{array}{l}\text { Reduction of ventricular } \\
\text { size to the level of wt } \\
\text { littermates }\end{array}$ \\
\hline
\end{tabular}


Table 2 Summary of the efficacy of the different intrabodies against HD (Continued)

\begin{tabular}{|c|c|c|c|c|}
\hline & & Body weight & $\begin{array}{l}\text { Assessment weekly from } 4 \text { wk } \\
\text { until death }\end{array}$ & No effect \\
\hline & & Aggregation & $\begin{array}{l}\text { Striatal immunostaining with } \\
\text { anti-Htt MW8 (detect aggregates } \\
\text { only) and nuclear marker; } \\
\text { counting of positive foci } \\
\text { (10 week-old mice). }\end{array}$ & $\begin{array}{l}\text { Reduction of the number } \\
\text { of both neuropil and } \\
\text { intranuclear aggregates. }\end{array}$ \\
\hline & & Life span & $\begin{array}{l}\text { Once ill, twice a day assessment } \\
\text { of righting reflex }\end{array}$ & No effect \\
\hline $\begin{array}{l}\text { N171-82Q: } \\
\text { hHtt }^{171 a a}-82 \mathrm{Q}\end{array}$ & $\begin{array}{l}\text { Four-week old male mice and } \\
\text { wt littermates: bilateral striatal } \\
\text { injection of GFP- or Happ1-AAV }\end{array}$ & $\begin{array}{l}\text { Motor } \\
\text { performances }\end{array}$ & $\begin{array}{l}\text { Latency to fall with accelerating } \\
\text { rotarod (every } 2 \text { wks from wk6 } \\
\text { until death) }\end{array}$ & $\begin{array}{l}\text { Significant improvement } \\
\text { from wk } 20 \text { to } 40 \text { at the } \\
\text { level of wt mice }\end{array}$ \\
\hline & & & $\begin{array}{l}\text { Beam-crossing performance } \\
\text { (every } 2 \text { wks from wk6 until death) }\end{array}$ & $\begin{array}{l}\text { Significant improvement } \\
\text { with reduction of time to } \\
\text { cross the three beams vs } \\
\text { GFP-AAV treated and wt } \\
\text { mice. }\end{array}$ \\
\hline & & & Clasping (22-week-old mice) & $\begin{array}{l}\text { Attenuation of clasping } \\
\text { behavior }\end{array}$ \\
\hline & & Body weight & $\begin{array}{l}\text { Assessment every } 2 \text { wks from wk6 } \\
\text { until death }\end{array}$ & $\begin{array}{l}\text { Increased weight vs GFP- } \\
\text { AAV treated but not to } \\
\text { the level of wt littermates } \\
\text { (from wk 22) }\end{array}$ \\
\hline & & Life span & $\begin{array}{l}\text { Once ill, twice a day assessment } \\
\text { of righting reflex }\end{array}$ & $\begin{array}{l}33 \% \text { increase of } \\
\text { maximum life-span (from } \\
30 \text { to } 40 \text { wk) vs GFP-AAV } \\
\text { treated mice. }\end{array}$ \\
\hline $\begin{array}{l}\text { BACHD: Full- } \\
\text { length- hHtt- } \\
\text { 97Q- }\end{array}$ & $\begin{array}{l}\text { 2-months-old male mice and } \\
\text { wt littermates: bilateral striatal } \\
\text { injection of GFP- or Happ1-AAV }\end{array}$ & $\begin{array}{l}\text { Motor } \\
\text { performances }\end{array}$ & $\begin{array}{l}\text { Rotarod latency to fall (monthly } \\
\text { from month } 3 \text { to } 6 \text { ) }\end{array}$ & $\begin{array}{l}\text { Increased latency to fall } \\
\text { in 5- and 6- month-old } \\
\text { mice }\end{array}$ \\
\hline & & & $\begin{array}{l}\text { Beam-crossing performances } \\
\text { (monthly from month } 3 \text { to 6) }\end{array}$ & $\begin{array}{l}\text { Decrease time to cross } \\
\text { the beams at } 5 \text { and } \\
6 \text { months }(28 \mathrm{~mm} \text { beam }) \\
\text { and at month } 6(6 \mathrm{~mm} \\
\text { beam) }\end{array}$ \\
\hline & & & Climbing time (6-month-old mice) & $\begin{array}{l}\text { Increased climbing time } \\
\text { vs GFP treatment }\end{array}$ \\
\hline & & $\begin{array}{l}\text { Cognitive } \\
\text { performances } \\
\text { (spatial and cortical } \\
\text { learning) }\end{array}$ & $\begin{array}{l}\text { Novel object location and novel } \\
\text { object preference tests (6-month- } \\
\text { old mice) }\end{array}$ & No effect \\
\hline & & Anxiety & Open field test & $\begin{array}{l}\text { Significant effect vs GFP- } \\
\text { AAV treated mice }\end{array}$ \\
\hline
\end{tabular}


Table 2 Summary of the efficacy of the different intrabodies against HD (Continued)

\begin{tabular}{|c|c|c|c|c|c|c|c|}
\hline & & & & & Brain atrophy & $\begin{array}{l}\text { Ventricular size assessment } \\
\text { (6-month-old mice) }\end{array}$ & $\begin{array}{l}\text { Reduction of ventricular } \\
\text { size }\end{array}$ \\
\hline & & & & & Body weight & $\begin{array}{l}\text { Assessment monthly (from } 3 \text { to } \\
6 \text { months of age) }\end{array}$ & No effect \\
\hline \multirow{9}{*}{$\begin{array}{l}\text { mEM48 } \\
\text { intrabody } \\
\text { (Wang et al., } \\
\text { 2008) [52] }\end{array}$} & \multirow{9}{*}{$\begin{array}{l}\text { VA residues } \\
\text { after the } \\
\text { polyP } \\
\text { region }\end{array}$} & \multirow[t]{3}{*}{ Cell culture } & HEK293 & $\begin{array}{l}\text { Co-transfection: hHtt }{ }^{208 a a} \\
23 / 130 Q \pm E M 48\end{array}$ & Cell survival & $\%$ of co-transfected dead cells & Improved cell viability \\
\hline & & & $\begin{array}{l}\text { Rat cortical } \\
\text { neurons }\end{array}$ & $\begin{array}{l}\text { Co-transfection: } \mathrm{hHtt} \\
\text { 23/130Q } \pm \text { EM48 }\end{array}$ & $\begin{array}{l}\text { Neuritic disruption } \\
\text { and pyknotic nuclei }\end{array}$ & Neuronal morphology & $\begin{array}{l}\text { Significant reduction of } \\
\text { transfected neurons with } \\
\text { disrupted neurites or } \\
\text { fragmented nuclei }\end{array}$ \\
\hline & & & PC12 cells & $\begin{array}{l}\text { Transfection of } \mathrm{hHtt}^{208 a \mathrm{a}} 23 / \\
130 \mathrm{Q} \pm \mathrm{AAV}-\mathrm{EM} 48\end{array}$ & $\begin{array}{l}\text { Neuropil } \\
\text { aggregates }\end{array}$ & Immunostaining & $\begin{array}{l}\text { Significant reduction of } \\
\text { neuropil aggregates }\end{array}$ \\
\hline & & \multirow[t]{6}{*}{ Mouse model } & $\begin{array}{l}\text { R6/2 (hhtt } \mathrm{ex}_{-} \\
144 \mathrm{Q})\end{array}$ & $\begin{array}{l}\text { Intrastriatal injection of helper } \\
\text { dependent AAV EM48 } \\
\text { (7-wk-old mice) }\end{array}$ & $\begin{array}{l}\text { Neuropil } \\
\text { aggregates }\end{array}$ & $\begin{array}{l}\text { Immunostaining ( } 4 \text { wk after } \\
\text { injection) }\end{array}$ & $\begin{array}{l}\text { Significant less neuropil } \\
\text { aggregates vs non } \\
\text { injected region; no effect } \\
\text { on intranuclear inclusion }\end{array}$ \\
\hline & & & \multirow[t]{5}{*}{ N171-82Q } & \multirow[t]{5}{*}{$\begin{array}{l}\text { Bilateral striatal injection of } \\
\text { helper dependent AAV EM48 } \\
\text { (10-wk-old mice) }\end{array}$} & $\begin{array}{l}\text { Neuropil } \\
\text { aggregates }\end{array}$ & $\begin{array}{l}\text { Immunostaining (6 wk after } \\
\text { injection) }\end{array}$ & $\begin{array}{l}\text { Significant less neuropil } \\
\text { aggregates vs non } \\
\text { injected region; no effect } \\
\text { on intranuclear inclusions }\end{array}$ \\
\hline & & & & & \multirow[t]{2}{*}{$\begin{array}{l}\text { Motor } \\
\text { performances }\end{array}$} & $\begin{array}{l}\text { Stride length (8-wk post } \\
\text { injection) }\end{array}$ & Improvement \\
\hline & & & & & & $\begin{array}{l}\text { Rotarod latency to fall (8-wk } \\
\text { post injection) }\end{array}$ & Significant improvement \\
\hline & & & & & Body weight & & No effect \\
\hline & & & & & Survival & & No effect \\
\hline $\begin{array}{l}\text { Monoclonal } \\
\text { antibodies } \\
1 \text { C2 (Heiser et } \\
\text { al., } 2000 \text { [43]; } \\
\text { Trottier et al., } \\
\text { 1995) [42] }\end{array}$ & $\begin{array}{l}\text { PolyQ } \\
\text { chain } \\
\text { (soluble) }\end{array}$ & Cell culture & $\cos -1$ & $\begin{array}{l}\text { Co-transfection: } \mathrm{hHtt} \mathrm{Ht}^{\mathrm{ex}} \\
-51 \mathrm{Q} \pm 1 \mathrm{C2}\end{array}$ & Aggregation & Filter retardation assay & $\begin{array}{l}\text { Up to } 85 \% \text { reduction in } \\
\text { aggregates }\end{array}$ \\
\hline
\end{tabular}

Legend: To characterize $\mathrm{Htt}$ fragments we use the general indication $\mathrm{Htt}^{\mathrm{Xaa}}-\mathrm{YQ}$ : the length of the fragment is expressed as a number $\mathrm{X}$ of amino acids (aa) (superimposed); the length of polyQ expansion is expressed as a number $\mathrm{Y}$ of $\mathrm{Q}$. 
Table 3 Summary of the efficacy of P42 in cellular, Drosophila, and mouse R6/2 HD models

\begin{tabular}{|c|c|c|c|c|c|c|}
\hline Peptide & Model & Population & Way of administration & End point & Method of evaluation & Results \\
\hline $\begin{array}{l}\text { P42 } \\
\text { (Arribat et al., 2013) [55] }\end{array}$ & Cell culture & $\begin{array}{l}\text { HeLa cells } \\
\left.\text { (hHtt }{ }^{171 a a}-136 \mathrm{Q}\right)\end{array}$ & $\begin{array}{l}\text { Co-transfection: polyQHtt + } \\
\text { P42 or empty vector }\end{array}$ & Htt aggregation & $\begin{array}{l}\text { Immunostaining; filter } \\
\text { retardation assays }\end{array}$ & Rescue $=80 \%$ \\
\hline \multirow[t]{2}{*}{$\begin{array}{l}\text { P42TAT } \\
\text { (Arribat et al., 2014) [61] }\end{array}$} & \multirow[t]{2}{*}{ Cell culture } & \multirow[t]{2}{*}{$\begin{array}{l}\text { HeLa cells } \\
\left.\text { (hHtt }{ }^{171 a a}-136 \mathrm{Q}\right)\end{array}$} & $\begin{array}{l}\text { Co-transfection: polyQHtt + } \\
\text { P42TAT or empty vector }\end{array}$ & Htt aggregation & $\begin{array}{l}\text { Immunostaining; filter } \\
\text { retardation assays }\end{array}$ & Rescue = $80 \%$ \\
\hline & & & $\begin{array}{l}\text { P42TAT-TAMRA provided in } \\
\text { culture cell medium }\end{array}$ & Htt aggregation & $\begin{array}{l}\text { Immunostaining; } \\
\text { filter retardation assays }\end{array}$ & $\begin{array}{l}\text { Rescue }=90 \% \text { (P42TAT } \\
\text { concentration dependent) }\end{array}$ \\
\hline \multirow[t]{5}{*}{$\begin{array}{l}\text { P42 } \\
\text { (Arribat et al., 2013) [55] }\end{array}$} & \multirow[t]{5}{*}{ HD Drosophila } & $\begin{array}{l}\text { MS-1096-Gal4; UAS- } \\
\text { HA-hHtt }{ }^{171 a a}-138 \mathrm{Q}\end{array}$ & $\begin{array}{l}\text { Genetic cross: UAS-P42 vs } \\
\text { UAS-LacZ (neutral control) }\end{array}$ & Htt aggregation & $\begin{array}{l}\text { Immunostaining; } \\
\text { filter retardation assays } \\
\text { (L3 larval salivary glands) }\end{array}$ & Rescue $=80 \%$ \\
\hline & & $\begin{array}{l}\text { GMR-Gal4; UAS- } \\
\mathrm{hHtt}^{\mathrm{ex}}-93 \mathrm{Q}\end{array}$ & $\begin{array}{l}\text { Genetic cross: UAS-P42 vs } \\
\text { UAS- GFP (neutral control) }\end{array}$ & Eye toxicity & $\begin{array}{l}\text { Phenotypical comparative } \\
\text { analysis (eyes of adult flies) }\end{array}$ & Rescue $=100 \%$ \\
\hline & & $\begin{array}{l}\text { OK6-Gal4/UAS-NPY- } \\
\text { GFP; UAS-hHtt5 }{ }^{58 a a}-128 \mathrm{Q}\end{array}$ & $\begin{array}{l}\text { Genetic cross: UAS-P42 vs } \\
\text { UAS-LacZ (neutral control) }\end{array}$ & Larval locomotion & Locomotion (mm/min) & Rescue close to $100 \%$ \\
\hline & & $\begin{array}{l}\text { OK6-Gal4/UAS-NPY- } \\
\text { GFP; UAS-hHtt5 }{ }^{548 a a}-128 \mathrm{Q}\end{array}$ & $\begin{array}{l}\text { Genetic cross: UAS-P42 vs } \\
\text { UAS-LacZ (neutral control) }\end{array}$ & Axonal transport & $\begin{array}{l}\text { Immunostaining and live } \\
\text { imaging to quantify different } \\
\text { parameters of Neuropeptide } \\
\text { Y vesicles trafficking in larval } \\
\text { motoneurons. }\end{array}$ & $\begin{array}{l}\text { Recovery of the different } \\
\text { parameters: Number of } \\
\text { vesicles: } 28 \% \text {; } \% \text { of } \\
\text { pausing: } 21 \% \text {; velocity: } 31 \%\end{array}$ \\
\hline & & $\begin{array}{l}\text { ELAV-Gal4; UAS-hHtt }{ }^{548 a a} \\
-128 \mathrm{Q}\end{array}$ & $\begin{array}{l}\text { Genetic cross: UAS-P42 vs } \\
\text { UAS-LacZ (neutral control) }\end{array}$ & Adult survival & $\begin{array}{l}\text { Mean, median, and maximal } \\
\text { survival (days) }\end{array}$ & $\begin{array}{l}\text { Increased median survival } \\
\text { (day } 18 \text { to 26); no effect on } \\
\text { mean and maximal survival }\end{array}$ \\
\hline \multirow[t]{5}{*}{$\begin{array}{l}\text { P42TAT } \\
\text { (Arribat et al., 2014) [61] }\end{array}$} & \multirow[t]{5}{*}{ R6/2 mice } & \multirow[t]{5}{*}{$\mathrm{hH} \mathrm{Ht}^{\mathrm{ex}}-140 \mathrm{Q}$} & \multirow{5}{*}{$\begin{array}{l}\text { Transmucosal daily administration } \\
\text { of P42TAT with Aonys }{ }^{\oplus} \text { water-in-oil } \\
\text { microemulsion }(600 \mu \mathrm{g} / \mathrm{ml} / \mathrm{kg} \text { ) vs } \\
\text { empty microemulsion at pre- } \\
\text { symptomatic (wk2 to wk11) R6/2 } \\
\text { and Wt mice. }\end{array}$} & Motor performance & $\begin{array}{l}\text { Latency to fall from accelerating } \\
\text { rotarod (weeks 6, 8, and 10) }\end{array}$ & $\begin{array}{l}\text { Significant amelioration } \\
\text { compared to placebo- } \\
\text { treated R6/2 mice }\end{array}$ \\
\hline & & & & Clasping test & $\begin{array}{l}\text { Frequency and duration of the } \\
\text { foot-clasping posture (twice a } \\
\text { week at wk } 7,9 \text {, and 11) }\end{array}$ & $\begin{array}{l}\text { Complete rescue vs placebo- } \\
\text { treated } R 6 / 2 \text { and to wt mice }\end{array}$ \\
\hline & & & & Weight loss & $\begin{array}{l}\text { Weight measure between } \\
\text { wk8 and wk10 }\end{array}$ & $\begin{array}{l}\text { Significant reversion of body } \\
\text { weight loss curve vs placebo- } \\
\text { treated mice }\end{array}$ \\
\hline & & & & $\begin{array}{l}\text { Intranuclear brain } \\
\text { aggregates; astrogliosis }\end{array}$ & $\begin{array}{l}\text { Immunostaining: number and } \\
\text { size of cortical and striatal } \\
\text { intranuclear aggregates; } \\
\text { cortical and striatal astrocyte } \\
\text { number }\end{array}$ & $\begin{array}{l}\text { Significant } 50 \% \text { reduction } \\
\text { of cortical and striatal } \\
\text { aggregates; non significant } \\
\text { reduction of the astrogliosis }\end{array}$ \\
\hline & & & & Cerebral atrophy & Lateral ventricle enlargement & Rescue = $30 \%$ \\
\hline
\end{tabular}


Monoclonal antibodies were also generated, such as $1 \mathrm{C} 2$ [42], able to specifically recognize the conformation of an elongated polyQ form in soluble proteins, but not the CAG sequence in insoluble aggregates of polyQ proteins, suggesting that $1 \mathrm{C} 2$ reduced aggregation, probably by stabilizing the polyQ protein in a native, soluble form and preventing aggregation-prone conformational changes [43].

Finally, several intracellular antibodies, known as intrabodies, binding to different part of the N-terminal Htt have also been identified to date. The intrabodies identified so far recognize a region in Htt other than the polyQ stretch itself and are therefore potentially specific for Htt protein, although cross-reactivity with other proteins cannot be excluded. Some intrabodies, like C4 [44-47] and $\mathrm{V}_{\mathrm{L}} 12.3$ [48] bind to the first 17aa of $\mathrm{Htt}$ (N17 region): they act by preventing aggregation and forming soluble complexes with the Htt-N-terminal part, which subsequently may undergo normal protein turnover; the levels of soluble wt and polyQHtt were therefore reported as increased [45] or unchanged [49] (Table 2). Other intrabodies (HAPP1, HAPP3, and MW7) [49] [50, 51] bind to the Proline Reach Region (PRR) domain: they act mainly by enhancing the degradation of the mutant protein which reduces soluble polyQHtt levels [49] (Table 2). Finally, another intrabody (mEM48), directed to the Valine/Alanine amino acid residues after the PRR tract, might alter the conformation of mutant $\mathrm{Htt}$, leading to its degradation via the ubiquitin-proteasome system [52]. The expression of these intrabodies was shown to be efficient in suppressing Htt aggregation and neurodegeneration when tested in a Drosophila model, through genetic expression in transgenic flies, [45] and in mouse models of HD, through conjugation with a viral vector and after an intra-striatal injection $[47,51,52]$ (Table 2). The use of intrabodies is therefore an attractive therapeutic approach with regard to their high binding affinity to the disease-causing proteins and their potential specificity for HD. Moreover some intrabodies are very small, therefore reducing problems of immunogenicity and allowing the passage in nuclear pore; this could be particular important considering the toxic role of some cleaved $\mathrm{N}$-terminal $\mathrm{Htt}$ fragments and their nuclear localisation [53]. However, major concerns about the therapeutic utilisation of intrabodies are the way of administrations and the possible unfavourable side effects due to cross-reactivity with the wild type Htt or to the fact that they are non-physiological entities.

Globally antibody- or peptide-based therapies seem to be very efficacious in ameliorating biological and clinical features of HD in different models; major drawbacks for their in vivo use are their rapid degradation by proteases and their poor blood-brain barrier and cellular membranes permeability, leading to an important difficulty in targeting central nervous system (CNS) neurons.

\section{Identification of the P42 peptide and efficacy on cellular and Drosophila HD models}

We have recently identified a new domain of $\mathrm{Htt}$ that is also acting on aggregation. We first observed that the 548 aa N-terminal part of normal human Htt (hHtt) or the 620 aa N-terminal part of Drosophila Htt homolog (dHtt) were sufficient to prevent polyQHtt aggregation in both HeLa cell and fly HD models [54]. Therefore, we searched for N-terminal region peptides sharing homologies between the human and the fly Htt protein, and playing a protective role on polyQHtt-induced phenotypes [55]. We first sequentially screened peptides designed from the hHtt protein, and identified a 23 aa peptide (P42) that shared homologies with its Drosophila counterpart.

The P42 peptide (“AASSGVSTPGSAGHDIITEQPRS”) is derived from the 480-502 aa region of the endogenous hHtt and lies within a region rich in proteolytic sites that play a critical role in the pathogenesis process (Fig. 1a) [56-58]. When the P42 sequence was included in an expressing vector and provided by co-transfection to polyQHtt HeLa cells, it was able of inhibiting polyQHtt aggregation, as efficiently as human longer peptides covering this domain: Htt-548aa or P4-166aa [55] (Fig. 1b). P42 was subsequently tested in Drosophila models of HD. To this end, flies expressing polyQHtt were crossed with transgenic flies expressing P42. P42 was found to reduce polyQHtt cytoplasmic aggregates in larval salivary glands and motoneurons, to ameliorate larval locomotion, and to prevent the polyQHtt-induced alteration of vesicular trafficking along the axons of larval motoneurons. P42 also prevented polyQ-induced eye neurodegeneration, characterized by eye depigmentation and abnormal ommatidial arrays; P42 expression in transgenic polyQ flies does not increase survival, although it ameliorates the median of the survival [55] (Table 3).

\section{Modifications of P42 and efficacy on cellular and mouse HD models}

Conjugation of P42 with a protein transduction domain

To overcome the problems of cell membrane penetration and brain delivery, we conjugated P42 to a cell penetrating peptide (CPP), as already developed for QBP1 [39, 40]. However, instead of using Antennapedia, we used a 11-aa peptide (YGRKKRRQRRR) part of the TAT protein, derived from the HIV; the same CPP was subsequently conjugated to the caspase -6 inhibiting ED11 peptide, and found efficient after intra-peritoneal administration [41]. In HeLa cells expressing polyQHtt, the fusion peptide P42-TAT supplemented in cell culture medium was able to penetrate cells and prevent aggregate formation [55] (Table 3); increasing concentrations of P42-TAT synthetic peptide (from $0.1 \mu \mathrm{M}$ to $20 \mu \mathrm{M}$ ) drove a clear dose-response effect with a complete inhibition of aggregation in presence of $10 \mu \mathrm{M}$ peptide 


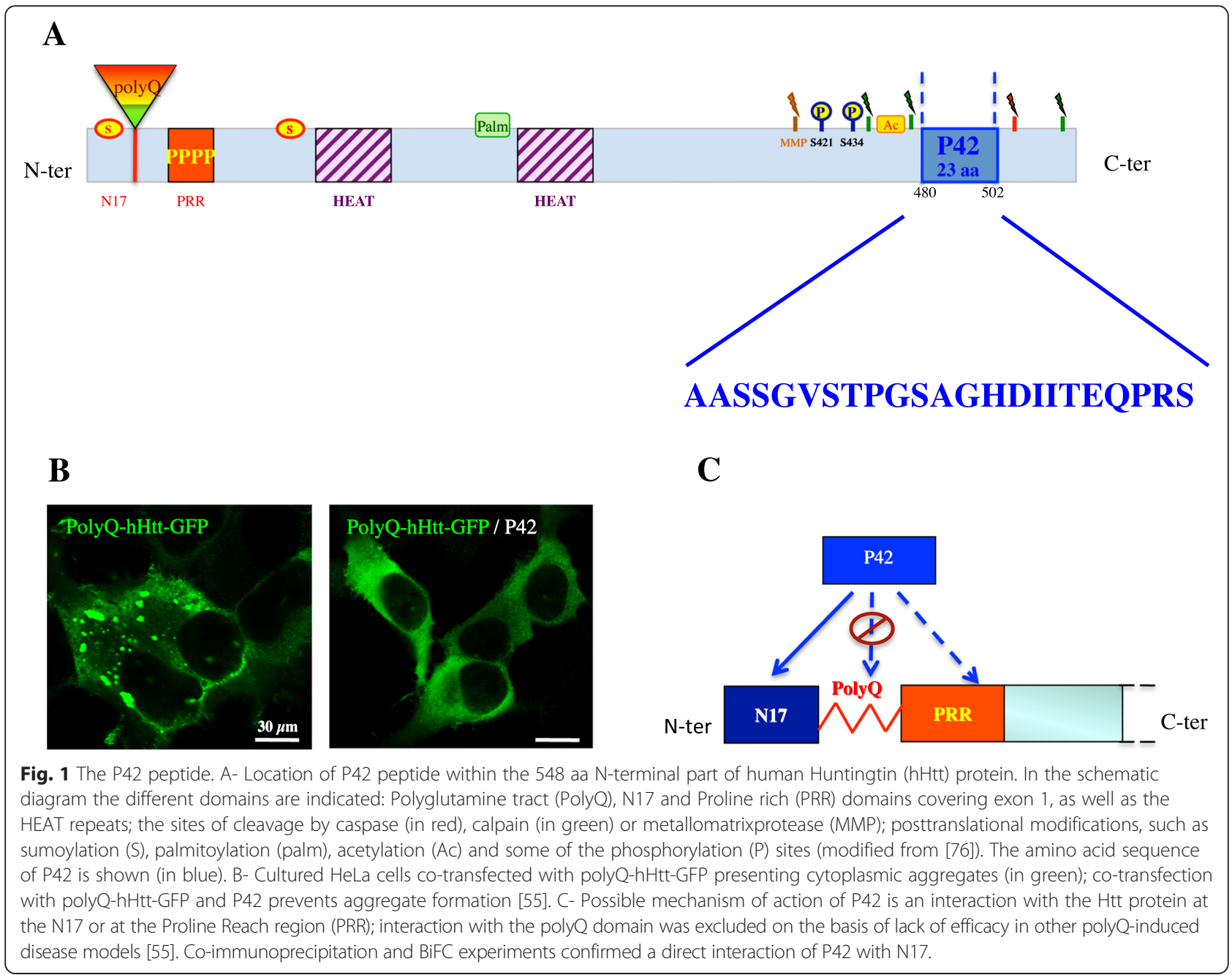

(Table 3). Note that even a 20-fold excess of this protective dose only produced $25 \%$ mortality, as assessed by the MTT (3-(4,5-dimethylthiazol-2-yl)-2,5-diphenyltetrazolium bromide) colorimetric test, while the IC50 value could not be measured, suggesting a low toxicity of the peptide on cell survival. In case of other small molecules [43], intrabodies, [49, 50, 52], or peptides [41], IC50 value was rather calculated in presence of polyQHtt protein to measure their efficacy in blocking aggregation and cell toxicity.

\section{Insertion of P42TAT into water-in-oil microemulsion, transmucosal administration and efficacy on mouse model}

Although the conjugation to TAT overcame the problem of cell membrane penetration, the issues of peptide degradation, delivery to the central nervous system, and non-invasive administration were still unresolved. In order to optimize the pharmacokinetic characteristics of P42 (serum half life and distribution profile) and to provide a non-invasive route for repetitive delivery of this fusion peptide, we used a novel water-in-oil microemulsion drug delivery vector named Aonys, developed by Medesis Pharma (France) $[59,60]$. Aonys ${ }^{\oplus}$ provides a transmucosal (buccal/rectal) route for drug administration which enhances CNS penetration [61]. This technology was also used for efficient CNS targeting after systemic delivery of lithium in a YAC128 mouse model of HD [62] and of small interfering RNA (siRNA) in a mouse model of prion disease [63]. The studies on P42 diffusivity showed that $3 \mathrm{~h}$ after intra-cerebroventricular injections of P42TAT in wild-type C57BL/6 J mice, a tagged form of the peptide (TAMRA-P42TAT) could widely diffuse and be found in different neuronal populations (neurons and astrocytes) and in different cellular compartments (nucleus and cytoplasm), in both the cortex and striatum. The same results were obtained after transmucosal P42TAT water-in-oil microemulsion administration. These data showed that P42TAT has the ability to diffuse into the brain in the different cell layers, including the striatum and that P42-TAT is able to reach the brain when administrated orally via Aonys ${ }^{\oplus}$ microemulsion. 
The protective effect of Aonys ${ }^{\oplus}$-formulated fusion peptide was tested in the R6/2 HD mouse model: knowing that symptoms appear at week 6 in these mice, daily transmucosal administration of P42TAT was performed at pre-symptomatic stage (from week 2 to week 11), and was able to improve the motor performances and to reduce polyQ aggregation in the brain, weigh loss, and brain atrophy; the administration of $\mathrm{P} 42$ was proved to be efficacious in the R6/2 HD mouse leading to an improvement of at least $30 \%$ recovery, according to the phenotype analysed [61] (Table 3).

\section{P42 mechanism of action on aggregation process}

Protein aggregation is a multistep process requiring an initial event, called nucleation, involving the N17 domain; during this nucleation step, polyQHtt adopts a structure able to associate with itself, which leads to an enhanced local concentration and oligomerization of the mutant hHtt; because of the presence of abnormal expanded polyQ stretches, these oligomers will further form parallel $ß$ sheets, seeding of the aggregation process [64]. The presence of N17 domain was shown to accelerate the aggregation process: intrabodies or proteins targeting the N17 domain are able to suppress aggregation and associated toxicity by inhibiting the initial nucleation step [44, 45, 47, 65-67]. Intrabodies against the PRR domain are also able to reduce polyQHtt aggregation and toxicity, mainly increasing turnover rate of mutant Htt $[49,51]$.

P42 showed to be able to improve phenotype in HD model expressing an expanded polyQ exon1 containing the N17, the PRR, and the polyQ domains, all playing a role in polyQHtt aggregation, suggesting a possible direct interaction between P42 and one of these N-terminal domains. Interestingly, genetic data from Drosophila models highlighted that $\mathrm{P} 42$ is not able to counteract eye degeneration in other polyQ-induced diseases different from HD, indicating that P42 mechanism of action is specific for $\mathrm{Htt}$ protein and therefore excluding an interaction with the polyQ domain [55]. Indeed, preliminary data including co-IP experiments and Bimolecular Fluorescent Complementation (BiFC) experiments suggest that P42 directly interacts with the N17 domain, therefore confirming the genetic data. This leads us to propose a model in which the addition of exogenous P42 interferes on aggregation process by blocking the initial step of nucleation, through its direct interaction with the N17 domain (Fig. 2).

However, the P42 mechanism of action could be more complex and polymorph: as a part of the Htt protein, it could be a functional protein domain and we cannot exclude a therapeutic effect linked to its normal physiological properties. Interestingly, P42 localised to the Tubulin network in vivo in Drosophila cells [54], and recently we confirmed that $\mathrm{P} 42$ binds microtubules (unpublished results). As Htt protein is involved in axonal trafficking [68] and P42 ameliorates the vesicular transport along the axons [55], P42 could therefore have a beneficial role modulating axonal transport, independently of its direct effect on aggregation.

\section{Conclusion}

Promising therapeutics for HD are under evaluation, notably nucleotide-based gene silencing methods. Both adeno-associated virus (AAV2) vector expressing HTT-silencing micro RNA (miRNA) [69] and intra-ventricular delivered antisense oligonucleotides (ASO) [70] were able to reduce the level of Htt mRNA and protein and to determine an amelioration on motor and behavioural features in different mouse (YAC128, BACHD, R6/2), and non human primate models of HD. Importantly, these studies showed an amelioration on already symptomatic mouse models, suggesting the reversibility of some features of the disease, although earlier treatments produce quicker and more robust reversal of disease; moreover, these studies showed that ASO injection determined a long-lasting transient suppression of $\mathrm{Htt}$ protein level, overcoming the period of ASO infusion, and that the amelioration of the disease in turns was evident for an extended period of time, exceeding the period of Htt suppression [70]. The existence of a phase I trial with ASO in humans in Amyotrophic Lateral Sclerosis [71] showing no acute toxicity and the possibility to measure mHtt level in CSF [72] in humans opened the way to a phase I study with intrathecal ASO in symptomatic HD patients. However some important issues are still opened such as selectivity toward $\mathrm{mHtt}$, consequences of a possible concomitant lowering of normal $\mathrm{Htt}$, sufficient targeting and diffusion in the brain after CSF infusion [30].

Whereas peptides and ASO are targeting early events, other new treatments are conceived with symptomaticonly effect or targeting later pathophysiological events and downwards interactors in the disease cascade, such as BDNF, the sirtuin system, or innate inflammation [30, 73].

Peptide-based drugs have been recently introduced in pipeline development and approved for therapy, notably to treat gastrointestinal disorders, hematological cancer, respiratory distress syndrome, Cushing syndrome, and anaemia in chronic kidney disease [74]. Physiological peptides can be biologically active and can be essential component of cell signalling pathways, immune system, hormonal systems, enzymatic systems and other important systems in the body. In the case of neurodegenerative diseases, various routes of delivery can be used: they could be injected to patients and newer methods like intranasal delivery [75], but also oral/ rectal mucosal administrations, are presently under investigation $[61,63]$. 


\section{A Model for aggregation in pathogenic conditions}

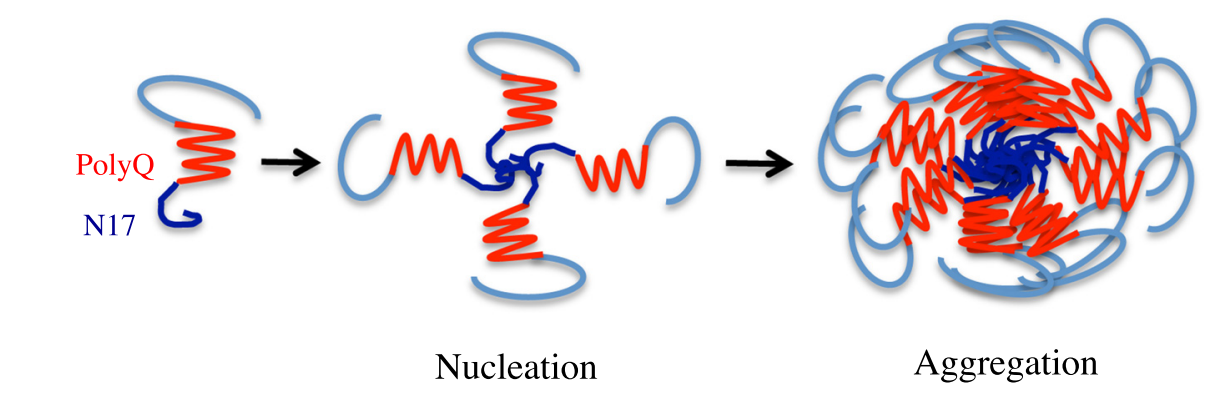

\section{B Model for the protective role of $\mathbf{P 4 2}$}

Fig. 2 Model of action of P42. A- In pathologic conditions, cleavage of mutant polyQHtt is increased, leading to short N-terminal fragments mostly lacking P42. N17 domains self interact, bringing together polyQHtt proteins (nucleation step). Oligomers will further form parallel $B$ sheets, thereby enhancing the aggregation process [64]. B- Our model is that exogenous addition of P42 allows a protective effect of polyQHtt-induced defects by directly interacting with the $\mathrm{N} 17$ domain of the N-terminal part of polyQHtt, therefore preventing nucleation, and consequently oligomerisation and aggregation processes.

Compared to other synthetic small molecule drugs, physiological peptides might offer lower toxicity, higher specificity, and fewer side effects [74]. Although most of the peptides developed against HD are artificiallyconceived peptides, $\mathrm{P} 42$ has the advantage to be derived from a sequence physiologically present in the $\mathrm{Htt}$ protein; this could be important to limit possible adverse events linked to immunogenicity.

As discussed in this review, peptide-based strategies could be potentially very efficacious in HD treatment because of their ability to target very initial steps in the pathophysiological cascade of the disease, such as aggregation or cleavage process. The efficacy of the different peptides studied until now was demonstrated in different models and on different phenotypes, including polyQHtt aggregation, eye degeneration, survival, larval motility, and axonal transport in the Drosophila HD model, and motor phenotype, weight loss, cognitive performances, cerebral polyQ aggregates, and cerebral atrophy in HD mouse model (Tables 1, 2 and 3). R6/2 mice are one of the models most frequently used to test peptide efficacy since it recapitulates many features of the disease found in humans with HD, such as intranuclear inclusion, weigh loss, motor and cognitive impairment, and brain atrophy. Remarkable results were obtained with peptide-based therapies in the R6/2 model concerning motor performances, body weight, aggregate formation, and brain atrophy; a prolongation of the lifespan was however only observed in the N171-82Q mouse model (Tables 1, 2 and 3). Other HD mouse model, such as full-length hHtt-97Q BACHD or YAC128 were most frequently used to test cognitive performances or anxiety, but in these models, the correct evaluation of the effect on Htt nuclear inclusions, brain atrophy and weight was complicated by the presence of milder or different (such as weight gain instead of weight loss) phenotypes in these less aggressive HD models (Tables 1 and 2). None of the peptide developed until now has been tested in knock-in HD mouse -models. 
Up to now, peptide stability and ability to target the central nervous system were major difficulties in the development of peptide at therapeutic ends. These problems were overcome during the development of $\mathrm{P} 42$ by conjugation with the TAT peptide transduction domain and using the water-in-oil microemulsion system developed by Aonys ${ }^{\circ}$ technology. These strategies allowed systemic non-invasive delivery associated with increased peptide stability and efficacious targeting of the central nervous system. Indeed, the association of P42 to TAT and microemulsions allowed reducing the amount of peripheral-administered peptide required to get sufficient peptide level in the central nervous system; non-invasive transmucosal oral administration could be an important issue in the context of a potential chronic administration to pre-symptomatic individuals to ensure patient compliance; finally, peptide stability could be further ameliorated and P42 administration can be potentially associated to other treatments to improve HD prognosis.

P42 could be particularly interesting because of its double role in targeting aggregation and in favouring some physiological function of normal $\mathrm{Htt}$, as it is naturally part of the Htt protein. Although P42 seems efficacious mainly at a pre-symptomatic stage we also found some effect at post-symptomatic stage in R6/2 mice, beginning treatments at week 7 when symptoms already started. Notably, an efficacy on motor performances and brain atrophy was observed after P42 administration to already symptomatic R6/2 mice. Further investigations suggested a beneficial effect of P42 on BDNF level, synaptic plasticity and neuronal activity, behavioural and cognitive aspects of the disease (unpublished results).

Therefore these results suggest that P42 offers a particular therapeutic potential not only by counteracting the effect of the mutant mHtt protein, but also by enhancing the physiological performances of the normal Htt protein. On the basis of these data P42 has recently obtained the designation as orphan medication for HD by the European Medicines Agency (EMA).

\begin{abstract}
Abbreviations
AAV2: adeno-associated virus; Antp: Antennapedia; ASO: antisense oligonucleotide; BDNF: brain-derived nerve factor; BiFC: bimolecular fluorescent complementation; CNS: central nervous system; CPP: cell penetrating peptides; dHtt: DrosophilaHuntingtin protein; EMA: European medicines agency; HD: Huntington's disease; hHtt: human Huntingtin protein; HTT: huntingtin human gene; Htt: Huntingtin protein; $\mathrm{mHtt}$ : mouse Huntingtin protein; miRNA: micro RNA; MJD: Machado-Joseph disease; MSN: striatal medium spiny neurons; MTT: 3-(4,5-dimethylthiazol-2-yl)-2,5diphenyltetrazolium bromide; polyQ: abnormal expanded polyglutamine strand; polyQHtt: mutant Htt protein with expanded polyQ; PRR: proline reach region domain; PTD: peptide transduction domains;

SCA3: spinocerebellar ataxia 3; siRNA: small interfering RNA; wt: wild type.
\end{abstract}

\section{Competing interests}

The authors declare that they have no competing interests.

\section{Authors' contributions}

Both CM and FM participated in the design and conception of the work and gave final approval of the version to be published; CM acquired data and drew a first draft; FM revised it critically for important intellectual content.

\section{Acknowledgments}

We would like to thank all the people contributing to the identification and developing of the P42 peptide and notably Yoan Arribat, Nathalie Bonneaud, Yasmina Talmat-Amar and Alexia Paucard. We would also thank all the people from Medesis Pharma, developing water-in-oil microemulsion, and notably Patrick Maurel. CM got financial support from the French ANR-14CE13-0035.

\section{Author details}

${ }^{1}$ Université de Montpellier, Montpellier F-34095, France; Inserm U1198 MMDN, Montpellier F-34095, France; EPHE, Paris F-75014, France, Montpellier, France. ${ }^{2}$ Department of Neurology, Gui de Chauliac University Hospital, Montpellier, France.

Received: 13 October 2015 Accepted: 8 March 2016

Published online: 17 March 2016

\section{References}

1. Walker FO. Huntington's disease. Lancet. 2007;369:218-28.

2. Roos RAC. Huntington's disease: a clinical review. Orphanet J Rare Dis. 2010;5:40.

3. Evans SJW, Douglas I, Rawlins MD, Wexler NS, Tabrizi SJ, Smeeth L. Prevalence of adult Huntington's disease in the UK based on diagnoses recorded in general practice records. J Neurol Neurosurg Psychiatry. 2013;84:1156-60.

4. A novel gene containing a trinucleotide repeat that is expanded and unstable on Huntington's disease chromosomes. The Huntington's Disease Collaborative Research Group. Cell 1993, 72:971-983

5. Vonsattel JP, Myers RH, Stevens TJ, Ferrante RJ, Bird ED, Richardson Jr EP. Neuropathological classification of Huntington's disease. J Neuropathol Exp Neurol. 1985;44:559-77.

6. DiFiglia M, Sapp E, Chase KO, Davies SW, Bates GP, Vonsattel JP, Aronin N. Aggregation of huntingtin in neuronal intranuclear inclusions and dystrophic neurites in brain. Science. 1997;277:1990-3.

7. Vonsattel JP, DiFiglia M. Huntington disease. J Neuropathol Exp Neurol. 1998;57:369-84.

8. Mestre T, Ferreira J, Coelho MM, Rosa M, Sampaio C. Therapeutic interventions for symptomatic treatment in Huntington's disease. Cochrane Database Syst Rev. 2009;3:CD006456.

9. Mestre TA, Ferreira JJ. An evidence-based approach in the treatment of Huntington's disease. Parkinsonism Relat Disord. 2012;18:316-20.

10. Burgunder J-M, Guttman M, Perlman S, Goodman N, van Kammen DP, Goodman L. An International Survey-based Algorithm for the Pharmacologic Treatment of Chorea in Huntington's Disease. PLoS Curr. 2011;3:RRN1260.

11. Venuto CS, McGarry A, Ma Q, Kieburtz K. Pharmacologic approaches to the treatment of Huntington's disease. Mov Disord Off J Mov Disord Soc. 2012;27:31-41.

12. Mestre T, Ferreira J, Coelho MM, Rosa M, Sampaio C. Therapeutic interventions for disease progression in Huntington's disease. Cochrane Database Syst Rev. 2009;3:CD006455.

13. Ross CA, Aylward EH, Wild EJ, Langbehn DR, Long JD, Warner JH, Scahill RI, Leavitt BR, Stout JC, Paulsen JS, Reilmann R, Unschuld PG, Wexler A, Margolis RL, Tabrizi SJ. Huntington disease: natural history, biomarkers and prospects for therapeutics. Nat Rev Neurol. 2014;10:204-16.

14. Ross CA, Tabrizi SJ. Huntington's disease: from molecular pathogenesis to clinical treatment. Lancet Neurol. 2011;10:83-98.

15. Ravikumar B, Rubinsztein DC. Role of autophagy in the clearance of mutant huntingtin: a step towards therapy? Mol Aspects Med. 2006;27:520-7.

16. Sherman MY, Goldberg AL. Cellular defenses against unfolded proteins: a cell biologist thinks about neurodegenerative diseases. Neuron. 2001;29:15-32.

17. Graham RK, Deng Y, Slow EJ, Haigh B, Bissada N, Lu G, Pearson J, Shehadeh J, Bertram L, Murphy Z, Warby SC, Doty CN, Roy S, Wellington CL, Leavitt BR, Raymond LA, Nicholson DW, Hayden MR. Cleavage at the caspase- 6 site is required for neuronal dysfunction and degeneration due to mutant huntingtin. Cell. 2006;125:1179-91. 
18. Zuccato C, Ciammola A, Rigamonti D, Leavitt BR, Goffredo D, Conti L, MacDonald ME, Friedlander RM, Silani V, Hayden MR, Timmusk T, Sipione S, Cattaneo E. Loss of huntingtin-mediated BDNF gene transcription in Huntington's disease. Science. 2001;293:493-8.

19. Mochel F, Haller RG. Energy deficit in Huntington disease: why it matters. J Clin Invest. 2011;121:493-9.

20. Weydt P, Pineda W, Torrence AE, Libby RT, Satterfield TF, Lazarowski ER, Gilbert ML, Morton GJ, Bammler TK, Strand AD, Cui L, Beyer RP, Easley CN, Smith AC, Krainc D, Luquet S, Sweet IR, Schwartz MW, La Spada AR. Thermoregulatory and metabolic defects in Huntington's disease transgenic mice implicate PGC-1alpha in Huntington's disease neurodegeneration. Cell Metab. 2006;4:349-62.

21. Cui $L$, Jeong H, Borovecki F, Parkhurst CN, Tanese N, Krainc D. Transcriptional repression of PGC-1alpha by mutant huntingtin leads to mitochondrial dysfunction and neurodegeneration. Cell. 2006;127:59-69.

22. Gunawardena S, Her L-S, Brusch RG, Laymon RA, Niesman IR, Gordesky-Gold B, Sintasath L, Bonini NM, Goldstein LSB. Disruption of axonal transport by loss of huntingtin or expression of pathogenic polyQ proteins in Drosophila. Neuron. 2003;40:25-40.

23. Gunawardena S, Goldstein LSB. Polyglutamine diseases and transport problems: deadly traffic jams on neuronal highways. Arch Neurol. 2005;62:46-51.

24. Cattaneo E, Zuccato C, Tartari M. Normal huntingtin function: an alternative approach to Huntington's disease. Nat Rev Neurosci. 2005;6:919-30.

25. Cattaneo E, Rigamonti D, Goffredo D, Zuccato C, Squitieri F, Sipione S. Loss of normal huntingtin function: new developments in Huntington's disease research. Trends Neurosci. 2001;24:182-8.

26. Lobsiger CS, Cleveland DW. Glial cells as intrinsic components of non-cellautonomous neurodegenerative disease. Nat Neurosci. 2007;10:1355-60.

27. Sapp E, Kegel KB, Aronin N, Hashikawa T, Uchiyama Y, Tohyama K, Bhide PG, Vonsattel JP, Difiglia M. Early and progressive accumulation of reactive microglia in the Huntington disease brain. J Neuropathol Exp Neurol. 2001; 60:161-72.

28. Tai YF, Pavese N, Gerhard A, Tabrizi SJ, Barker RA, Brooks DJ, Piccini P. Microglial activation in presymptomatic Huntington's disease gene carriers. Brain J Neurol. 2007;130(Pt 7):1759-66.

29. Giorgini F, Guidetti P, Nguyen Q, Bennett SC, Muchowski PJ. A genomic screen in yeast implicates kynurenine 3-monooxygenase as a therapeutic target for Huntington disease. Nat Genet. 2005;37:526-31.

30. Wild EJ, Tabrizi SJ. Targets for future clinical trials in Huntington's disease: what's in the pipeline? Mov Disord Off J Mov Disord Soc. 2014;29:1434-45.

31. Kazantsev A, Walker HA, Slepko N, Bear JE, Preisinger E, Steffan JS, Zhu Y-Z, Gertler FB, Housman DE, Marsh JL, Thompson LM. A bivalent Huntingtin binding peptide suppresses polyglutamine aggregation and pathogenesis in Drosophila. Nat Genet. 2002;30:367-76.

32. Nagai $Y$, Tucker $T$, Ren $H$, Kenan DJ, Henderson BS, Keene JD, Strittmatter WJ, Burke JR. Inhibition of polyglutamine protein aggregation and cell death by novel peptides identified by phage display screening. J Biol Chem. 2000;275: 10437-42

33. Nagai Y, Fujikake N, Ohno K, Higashiyama H, Popiel HA, Rahadian J, Yamaguchi M, Strittmatter WJ, Burke JR, Toda T. Prevention of polyglutamine oligomerization and neurodegeneration by the peptide inhibitor QBP1 in Drosophila. Hum Mol Genet. 2003:12:1253-9.

34. Derossi D, Joliot AH, Chassaing G, Prochiantz A. The third helix of the Antennapedia homeodomain translocates through biological membranes. J Biol Chem. 1994;269:10444-50.

35. Wadia JS, Dowdy SF. Protein transduction technology. Curr Opin Biotechnol. 2002;13:52-6.

36. Prochiantz A. For protein transduction, chemistry can win over biology. Nat Methods. 2007:4:119-20.

37. Morris MC, Depollier J, Mery J, Heitz F, Divita G. A peptide carrier for the delivery of biologically active proteins into mammalian cells. Nat Biotechnol. 2001;19:1173-6.

38. Khafagy E-S, Morishita M. Oral biodrug delivery using cell-penetrating peptide. Adv Drug Deliv Rev. 2012;64:531-9.

39. Popiel HA, Nagai Y, Fujikake N, Toda T. Protein transduction domainmediated delivery of QBP1 suppresses polyglutamine-induced neurodegeneration in vivo. Mol Ther J Am Soc Gene Ther. 2007;15:303-9.

40. Popiel HA, Nagai Y, Fujikake N, Toda T. Delivery of the aggregate inhibitor peptide QBP1 into the mouse brain using PTDs and its therapeutic effect on polyglutamine disease mice. Neurosci Lett. 2009;449:87-92.
41. Aharony I, Ehrnhoefer DE, Shruster A, Qiu X, Franciosi S, Hayden MR, Offen D. A Huntingtin-based peptide inhibitor of caspase- 6 provides protection from mutant Huntingtin-induced motor and behavioral deficits. Hum Mol Genet. 2015;24:2604-14.

42. Trottier Y, Lutz Y, Stevanin G, Imbert G, Devys D, Cancel G, Saudou F, Weber C, David G, Tora L. Polyglutamine expansion as a pathological epitope in Huntington's disease and four dominant cerebellar ataxias. Nature. 1995;378:403-6.

43. Heiser V, Scherzinger E, Boeddrich A, Nordhoff E, Lurz R, Schugardt N, Lehrach $\mathrm{H}$, Wanker EE. Inhibition of huntingtin fibrillogenesis by specific antibodies and small molecules: implications for Huntington's disease therapy. Proc Natl Acad Sci U S A. 2000;97:6739-44.

44. Lecerf JM, Shirley TL, Zhu Q, Kazantsev A, Amersdorfer P, Housman DE, Messer A, Huston JS. Human single-chain Fv intrabodies counteract in situ huntingtin aggregation in cellular models of Huntington's disease. Proc Nat Acad Sci U S A. 2001;98:4764-9.

45. Wolfgang WJ, Miller TW, Webster JM, Huston JS, Thompson LM, Marsh JL, Messer A. Suppression of Huntington's disease pathology in Drosophila by human single-chain Fv antibodies. Proc Natl Acad Sci U S A. 2005;102: 11563-8.

46. Murphy RC, Messer A. A single-chain Fv intrabody provides functional protection against the effects of mutant protein in an organotypic slice culture model of Huntington's disease. Brain Res Mol Brain Res. 2004;121:141-5.

47. Snyder-Keller A, McLear JA, Hathorn T, Messer A. Early or late-stage anti-Nterminal Huntingtin intrabody gene therapy reduces pathological features in B6.HDR6/1 mice. J Neuropathol Exp Neurol. 2010;69:1078-85.

48. Colby DW, Chu Y, Cassady JP, Duennwald M, Zazulak H, Webster JM, Messer A, Lindquist S, Ingram VM, Wittrup KD. Potent inhibition of huntingtin aggregation and cytotoxicity by a disulfide bond-free single-domain intracellular antibody. Proc Natl Acad Sci U S A. 2004;101:17616-21.

49. Southwell AL, Khoshnan A, Dunn DE, Bugg CW, Lo DC, Patterson PH. Intrabodies binding the proline-rich domains of mutant huntingtin increase its turnover and reduce neurotoxicity. J Neurosci Off J Soc Neurosci. 2008:28:9013-20.

50. Khoshnan A, Ko J, Patterson PH. Effects of intracellular expression of antihuntingtin antibodies of various specificities on mutant huntingtin aggregation and toxicity. Proc Natl Acad Sci U S A. 2002;99:1002-7.

51. Southwell AL, Ko J, Patterson PH. Intrabody gene therapy ameliorates motor, cognitive, and neuropathological symptoms in multiple mouse models of Huntington's disease. J Neurosci Off J Soc Neurosci. 2009:29:13589-602

52. Wang C-E, Zhou H, McGuire JR, Cerullo V, Lee B, Li S-H, Li X-J. Suppression of neuropil aggregates and neurological symptoms by an intracellular antibody implicates the cytoplasmic toxicity of mutant huntingtin. J Cell Biol. 2008:181:803-16.

53. Warby SC, Doty CN, Graham RK, Carroll JB, Yang Y-Z, Singaraja RR, Overall CM, Hayden MR. Activated caspase- 6 and caspase-6-cleaved fragments of huntingtin specifically colocalize in the nucleus. Hum Mol Genet. 2008;17:2390-404.

54. Mugat B, Parmentier M-L, Bonneaud N, Chan HYE, Maschat F. Protective role of Engrailed in a Drosophila model of Huntington's disease. Hum Mol Genet. 2008:17:3601-16.

55. Arribat $Y$, Bonneaud N, Talmat-Amar Y, Layalle S, Parmentier M-L, Maschat F. A huntingtin peptide inhibits polyQ-huntingtin associated defects. PloS One. 2013;8:e68775

56. Goldberg YP, Nicholson DW, Rasper DM, Kalchman MA, Koide HB, Graham RK Bromm M, Kazemi-Esfarjani P, Thornberry NA, Vaillancourt JP, Hayden MR. Cleavage of huntingtin by apopain, a proapoptotic cysteine protease, is modulated by the polyglutamine tract. Nat Genet. 1996;13:442-9.

57. Gafni J, Ellerby LM. Calpain activation in Huntington's disease. J Neurosci Off J Soc Neurosci. 2002;22:4842-9.

58. El-Daher M-T, Hangen E, Bruyère J, Poizat $\mathrm{G}$, Al-Ramahi I, Pardo R, Bourg N, Souquere S, Mayet C, Pierron G, Lévêque-Fort S, Botas J, Humbert S, Saudou F. Huntingtin proteolysis releases non-polyQ fragments that cause toxicity through dynamin 1 dysregulation. EMBO J. 2015;34:2255-71.

59. Mouri A, Diat O, El Ghzaoui A, Ly I, Dorandeu C, Maurel JC, Devoisselle J-M, Legrand P. Development of pharmaceutical clear gel based on Peceol ${ }^{\circledR}$, lecithin, ethanol and water: Physicochemical characterization and stability study. J Colloid Interface Sci. 2015:457:152-61.

60. Mouri A, Diat O, El Ghzaoui A, Bauer C, Maurel JC, Devoisselle J-M, Dorandeu C, Legrand P. Phase behavior of reverse microemulsions based on Peceol( ()$^{)}$. J Colloid Interface Sci. 2014;416:139-46. 
61. Arribat $Y$, Talmat-Amar Y, Paucard A, Lesport P, Bonneaud N, Bauer C, Bec N, Parmentier M-L, Benigno L, Larroque C, Maurel P, Maschat F. Systemic delivery of P42 peptide: a new weapon to fight Huntington is disease. Acta Neuropathol Commun. 2014;2:86.

62. Pouladi MA, Brillaud E, Xie Y, Conforti P, Graham RK, Ehrnhoefer DE, Franciosi S, Zhang W, Poucheret P, Compte E, Maurel J-C, Zuccato C, Cattaneo E, Néri C, Hayden MR. NP03, a novel low-dose lithium formulation, is neuroprotective in the YAC128 mouse model of Huntington disease. Neurobiol Dis. 2012;48:282-9.

63. Lehmann S, Relano-Gines A, Resina S, Brillaud E, Casanova D, Vincent C, Hamela C, Poupeau S, Laffont M, Gabelle A, Delaby C, Belondrade M, Arnaud J-D, Alvarez M-T, Maurel J-C, Maurel P, Crozet C. Systemic delivery of siRNA down regulates brain prion protein and ameliorates neuropathology in prion disorder. PloS One. 2014;9:e88797.

64. Bates G. Huntingtin aggregation and toxicity in Huntington's disease. Lancet. 2003;361:1642-4.

65. Tam S, Geller R, Spiess C, Frydman J. The chaperonin TRiC controls polyglutamine aggregation and toxicity through subunit-specific interactions. Nat Cell Biol. 2006;8:1155-62.

66. Tam S, Spiess C, Auyeung W, Joachimiak L, Chen B, Poirier MA, Frydman J. The chaperonin TRiC blocks a huntingtin sequence element that promotes the conformational switch to aggregation. Nat Struct Mol Biol. 2009;16:1279-85.

67. Colby DW, Garg P, Holden T, Chao G, Webster JM, Messer A, Ingram VM Wittrup KD. Development of a human light chain variable domain $(V(L))$ intracellular antibody specific for the amino terminus of huntingtin via yeast surface display. J Mol Biol. 2004;342:901-12.

68. Gauthier LR, Charrin BC, Borrell-Pagès M, Dompierre JP, Rangone $H$, Cordelières FP, De Mey J, MacDonald ME, Lessmann V, Humbert S, Saudou F. Huntingtin controls neurotrophic support and survival of neurons by enhancing BDNF vesicular transport along microtubules. Cell. 2004;118:127-38.

69. Stanek LM, Sardi SP, Mastis BM, Richards AR, Treleaven CM, Taksir TV, Misra $\mathrm{K}$, Cheng SH, Shihabuddin LS. Silencing mutant huntingtin by AAVmediated RNAi ameliorates disease manifestations in the YAC128 mouse model of Huntington's disease. Hum Gene Ther. 2014;25:461-74.

70. Kordasiewicz HB, Stanek LM, Wancewicz EV, Mazur C, McAlonis MM, Pytel KA, Artates JW, Weiss A, Cheng SH, Shihabuddin LS, Hung G, Bennett CF, Cleveland DW. Sustained therapeutic reversal of Huntington's disease by transient repression of huntingtin synthesis. Neuron. 2012;74:1031-44.

71. Miller TM, Pestronk A, David W, Rothstein J, Simpson E, Appel SH, Andres PL, Mahoney K, Allred P, Alexander K, Ostrow LW, Schoenfeld D, Macklin EA, Norris DA, Manousakis G, Crisp M, Smith R, Bennett CF, Bishop KM, Cudkowicz ME. An antisense oligonucleotide against SOD1 delivered intrathecally for patients with SOD1 familial amyotrophic lateral sclerosis: a phase 1, randomised, first-in-man study. Lancet Neurol. 2013;12:435-42.

72. Wild EJ, Boggio R, Langbehn D, Robertson N, Haider S, Miller JRC, Zetterberg H, Leavitt BR, Kuhn R, Tabrizi SJ, Macdonald D, Weiss A. Quantification of mutant huntingtin protein in cerebrospinal fluid from Huntington's disease patients. J Clin Invest. 2015;125:1979-86.

73. Shannon KM, Fraint A. Therapeutic advances in Huntington's Disease. Mov Disord. 2015;30:1539-46.

74. Kaspar AA, Reichert JM. Future directions for peptide therapeutics development. Drug Discov Today. 2013;18:807-17.

75. Hanson LR, Frey WH. Intranasal delivery bypasses the blood-brain barrier to target therapeutic agents to the central nervous system and treat neurodegenerative disease. BMC Neurosci. 2008;9 Suppl 3:S5.

76. Zuccato C, Valenza M, Cattaneo E. Molecular mechanisms and potentia therapeutical targets in Huntington's disease. Physiol Rev. 2010;90:905-81.

\section{Submit your next manuscript to BioMed Central and we will help you at every step:}

- We accept pre-submission inquiries

- Our selector tool helps you to find the most relevant journal

- We provide round the clock customer support

- Convenient online submission

- Thorough peer review

- Inclusion in PubMed and all major indexing services

- Maximum visibility for your research

Submit your manuscript at www.biomedcentral.com/submit
Ciomed Central 